\title{
Dinamička simulacija rada šaržnog polimerizacijskog reaktora i parametarska analiza homopolimerizacije stirena
}

DOI: $10.15255 /$ KUI.2013.039 KUI-10/2015 Stručni rad

Prispjelo 3. prosinca 2013. Prihvaćeno 14. svibnja 2014.

\author{
I. Šoljić Jerbić, S. Kuzmići A. Jukić*
}

Zavod za tehnologiju nafte i petrokemiju

Fakultet kemijskog inženjerstva i tehnologije Sveučilišta u Zagrebu

Savska cesta 16/II, 10000 Zagreb, Hrvatska

\begin{abstract}
\| Sažetak
Provedena je dinamička simulacija rada šaržnog polimerizacijskog reaktora za proces homopolimerizacije stirena u otopini ksilena iniciranog uz monofunkcijski i difunkcijski peroksidni inicijator. Monofunkcijski inicijator ima široku industrijsku primjenu, dok je difunkcijski u preliminarnim istraživanjima pokazao određene prednosti kao što su proizvodnja polimera homogenije strukture uz postizanje visokih ili čak potpunih konverzija monomera. Također, vrijeme reakcije može se znatno smanjiti bez potrebe za preinakom reaktorskog sustava. Računalna simulacija provedena je primjenom programskog sustava za simuliranje procesa ChemCAD, točnije njegova modula CC-Polymer, razvijenog isključivo za analizu i projektiranje radikalskih i stupnjevitih polimerizacijskih sustava. Na temelju kompleksnih kinetičkih modela program omogućava predviđanje osnovnih strukturnih svojstava polimera - raspodjele (disperznosti) i prosjeka molekulskih masa, koji izravno određuju kvalitetu i primjenu gotovih proizvoda. Ovisnosti konverzije monomera i strukturnih značajki polimera o vremenu polimerizacije izračunate računalnom simulacijom uspoređene su s eksperimentalno dobivenim rezultatima. Dobivene su istovjetne tendencije i razmjerno dobro slaganje za završetak polimerizacije pri većini ispitanih uvjeta. Provedena je i parametarska analiza za homopolimerizacijski sustav iniciran diperoksidnim inicijatorom. Ispitan je utjecaj koncentracije monomera, koncentracije inicijatora, temperature i vremena reakcije na konverziju monomera, brojčani i maseni prosjek molarnih masa te disperznost.
\end{abstract}

$\|$ Ključne riječi

Stiren, polimerizacija u otopini, difunkcijski peroksidni inicijator, kotlasti polimerizacijski reaktor, dinamička simulacija, parametarska analiza

\section{Uvod}

Od sedamdesetih godina 20. stoljeća, kada se polimerno reakcijsko inženjerstvo počelo razvijati kao znanstvena disciplina, i matematičko modeliranje polimerizacijskih reaktora postalo je vrlo detaljno i opsežno. ${ }^{1,2}$ Za razvoj prikladnog matematičkog modela nužno je poznavanje kinetike i reakcijskog mehanizma kojim se odvija proces polimerizacije, zatim konfiguracije polimernog reaktora i radnih uvjeta kako bi se predvidio njihov utjecaj na građu sintetiziranih makromolekula (na primjer, raspodjelu molekulskih masa, stupanj cijepljenja i drugo) kao i morfologiju polimernog proizvoda (na primjer, raspodjelu veličine čestica, poroznost i drugo). Kod polimerizacijskih procesa kvaliteta proizvoda vrlo je kompleksno pitanje jer o strukturnim i morfološkim karakteristikama polimera ovise njihova fizikalna, kemijska, toplinska, reološka i mehanička svojstva, pa tako i krajnja primjena. $U$ današnje vrijeme računalni programi za simulaciju (engl. Computer-Aided Design, CAD) rada polimerizacijskih reaktora smatraju se jednim od vrlo uspješnih alata koji znatno pridonose razvoju procesnih tehnologija kao i proizvodnji polimera., ${ }^{2,3}$ To uključuje projektiranje procesa, optimizaciju, procjenu parametara stanja i vođenje procesa. Stabilnost i vođenje

*Autor za dopisivanje: Prof. dr. sc. Ante Jukić

e-pošta: ajukic@fkit.hr rada polimerizacijskih reaktora mogu se preliminarno ispitati $\mathrm{i}$ provjeriti prije izgradnje postrojenja upotrebom dinamičkih reaktorskih modela. Takvi modeli mogu identificirati potencijalne izvore koji uzrokuju varijacije u kvaliteti proizvoda te ih svesti na najmanju mjeru, a bitni su i za razvoj odgovarajuće računalne podrške pri vođenju takvih procesa. ${ }^{4-7}$ Najznačajniju ulogu u razvoju polimerizacijskih procesa i proizvoda imaju procesni inženjeri jer njihovo dugogodišnje iskustvo i znanje o procesu kao i o modeliranju i programiranju znatno pridonosi stvaranju visokokvalitetnih proizvoda. Do danas je razvijeno nekoliko komercijalnih programskih paketa za simuliranje raznih polimerizacijskih procesa, a prvi takav bio je POLYRED, razvijen na sveučilištu Wisconsin. ${ }^{3}$

Prema mehanizmu rasta lanca i kinetici, reakcije polimerizacije razvrstavaju se u dvije velike skupine: stupnjevite ili postupne te lančane, koje se mogu odvijati radikalskim, ionskim i koordinativnim mehanizmom. Procesi lančanih radikalskih polimerizacija temeljni su i najviše upotrebljavani tehnološki postupci dobivanja polimernih materijala, a odvijaju se klasičnim mehanizamom radikalskih lančanih reakcija u kojemu su zastupljena najmanje tri stupnja elementarnih reakcija: inicijacija, propagacija i terminacija. Radikalskim mehanizmom polimerizira najveći broj vinilnih, dienskih, akrilatnih i metakrilatnih monomera stvarajući odgovarajuće homopolimere i velik broj kopolimera. 
Nedostatak mu je mala mogućnost utjecaja na strukturu nastalih polimernih molekula, posebice na raspodjelu molekulskih masa i disperznost, što je posljedica nestabilnosti i vrlo kratkog života slobodnih radikala. Iz teorije slobodno-radikalskih polimerizacija poznato je da se ne mogu istodobno postići velike brzine reakcije polimerizacije te proizvesti polimeri velikih molekulskih masa i uske raspodjele masa, koji su nužni za određene primjene..$^{8-12}$ Stoga je u posljednjih 10-ak godina razvijeno nekoliko novih postupaka sinteze kojima je moguće kontrolirati strukturnu građu sintetiziranih polimera odnosno molekulsku masu, raspodjelu molekulskih masa (disperznost), funkcijske skupine i sastav. Među njima se posebno ističe povrativo-deaktivacijska radikalska polimerizacija (prethodno nazivana kontrolirana radikalska ili živuća radikalska polimerizacija), gdje se polimerizacija provodi s novim inicirajućim sustavima kao što su različiti katalizatori, ionski i organometalni kompleksi. U takvom reakcijskom mehanizmu izostaju ter- minacija lanca i nepovrativi prijenos lanca. Ako su inicirajuće vrste u potpunosti potrošene prije znatnijeg rasta lanca, svi lanci rastu jednakom brzinom, pa molekulska masa raste linearno s vremenom odvijanja reakcije sve dok se ne istroši sav monomer prisutan u reakcijskoj smjesi. Također, i raspodjela molekulskih masa proizvoda može biti znatno uža nego u konvencionalnoj radikalskoj polimerizaciji. Međutim, za sada su nedostatci takvog postupka dobivanje polimera malih molekulskih masa, nemogućnost polimerizacije određenih vrsta monomera, osjetljivost sustava na oksidaciju kisikom iz zraka, uklanjanje katalizatora iz reakcijske smjese te obojenja koje uzrokuju. Iz tih su razloga mogućnosti takvih procesa za proizvodnju u mjerilu većemu od laboratorijskog još uvijek ograničene. ${ }^{13-19}$ Velike molekulske mase, uz njihovu razmjerno užu raspodjelu u usporedbi s konvencionalnim monofunkcijskim peroksidnim inicijatorima, mogu se pod određenim procesnim uvjetima postići primjenom višefunkcijskih peroksidnih ini-

\section{Monofunkcijski peroksidni inicijator Monofunctional peroxide initiator}

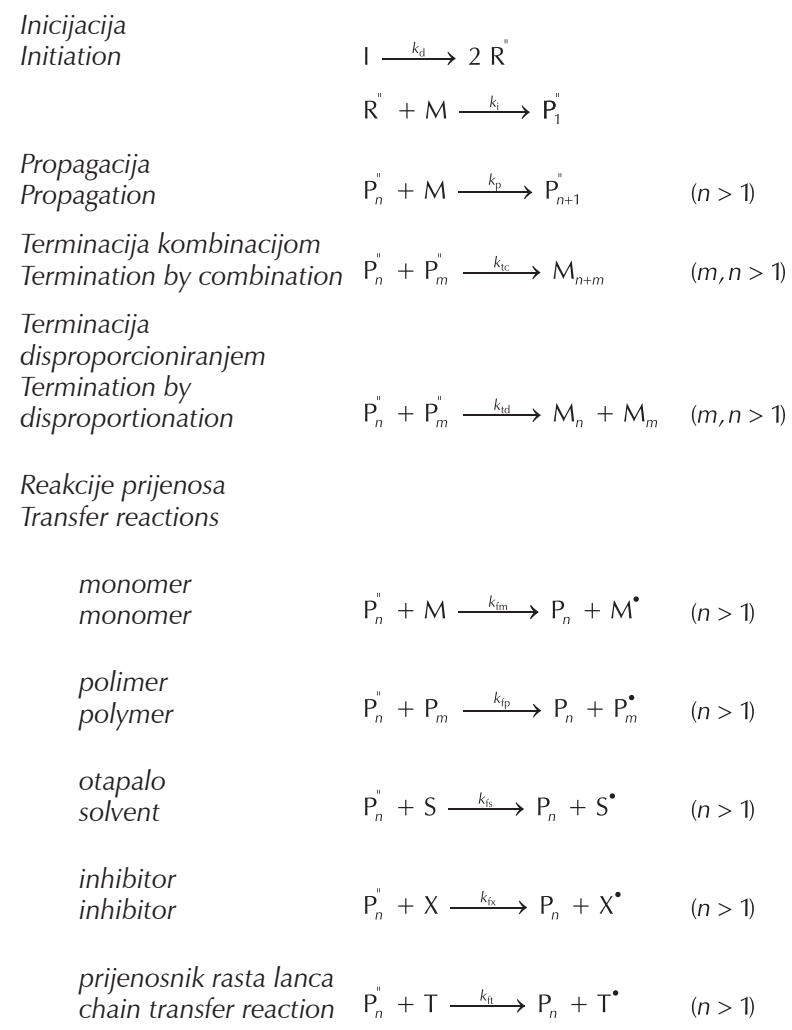

\section{Difunkcijski peroksidni inicijator Bifunctional peroxide initiator}

\author{
Razgradnja inicijatora \\ na primarne radikale \\ Degradation of initiator on the \\ primary radicals \\ $\mathrm{I}_{\mathrm{k}} \stackrel{2 k_{\mathrm{d} 1}}{\longrightarrow} \mathrm{R}_{1}^{\mathrm{n}}+\mathrm{R}_{2}^{\mathrm{n}}$ \\ Inicijacija primarnim radikalima \\ Initiation of the primary radicals $\quad \mathrm{R}_{1}^{\prime \prime}+\mathrm{M} \stackrel{k_{\mathrm{in}}}{\longrightarrow} \mathrm{P}_{1}^{\prime \prime}$ \\ $\mathrm{R}_{2}^{\prime \prime}+\mathrm{M} \stackrel{k_{\mathrm{i} 2}}{\longrightarrow} \mathrm{A}_{1}^{\prime \prime}$ \\ Naknadna razgradnja polimernih molekula s jednom $\left(\mathrm{N}_{n}\right)$ ili \\ s dvjema $\left(\mathrm{U}_{n}\right)$ peroksidnim skupinama \\ Subsequent degradation of polymer molecules with one $\left(\mathrm{V}_{n}\right)$ or \\ two $\left(\mathrm{U}_{n}\right)$ peroxide groups

$$
\begin{array}{ll}
\mathrm{U}_{n} \stackrel{2 k_{\mathrm{d} 2}}{\longrightarrow} \mathrm{A}_{n}^{\prime \prime}+\mathrm{R}_{1}^{\prime \prime} & (n>2) \\
\mathrm{A}_{n}^{\prime \prime} \stackrel{k_{\mathrm{d} 2}}{\longrightarrow} \mathrm{B}_{n}^{\prime \prime}+\mathrm{R}_{1}^{\prime \prime} & (n>1) \\
\mathrm{V}_{n} \stackrel{\mathrm{k}_{\mathrm{d} 2}}{\longrightarrow} \mathrm{P}_{n}^{\prime \prime}+\mathrm{R}_{1}^{\prime \prime} & (n>2)
\end{array}
$$ \\ Propagacija \\ Propagation $\quad \mathrm{P}_{n}^{\prime \prime}+\mathrm{M} \stackrel{k_{p}}{\longrightarrow} \mathrm{P}_{n+1}^{\prime \prime} \quad(n>1)$ \\ $\mathrm{A}_{n}^{\prime \prime}+\mathrm{M} \stackrel{k_{\rho}}{\longrightarrow} \mathrm{A}_{n+1}^{\prime \prime} \quad(n>1)$ \\ $\mathrm{B}_{n}^{\prime \prime}+\mathrm{M} \stackrel{2 k_{p}}{\longrightarrow} \mathrm{B}_{n+1}^{\prime \prime} \quad(n>1)$
}

Terminacija (pretpostavlja se da se terminacija odvija uglavnom kombinacijom) Termination (it is assumed that termination occurs mostly by combination)

$$
\begin{array}{ll}
\mathrm{P}_{n}^{\prime \prime}+\mathrm{P}_{m}^{\prime} \stackrel{k_{\mathrm{t}}}{\longrightarrow} \mathrm{M}_{n+m} & (m, n>1) \\
\mathrm{P}_{n}^{\prime \prime}+\mathrm{A}_{m}^{\prime \prime} \stackrel{k_{\mathrm{t}}}{\longrightarrow} \mathrm{V}_{n+m} & (m, n>1) \\
\mathrm{P}_{n}^{\prime \prime}+\mathrm{B}_{m}^{\prime} \stackrel{2 k_{\mathrm{t}}}{\longrightarrow} \mathrm{P}_{n+m} & (m, n>1) \\
& (m, n>1) \\
\mathrm{A}_{n}^{\prime \prime}+\mathrm{B}_{m}^{\prime \prime} \stackrel{2 k_{\mathrm{t}}}{\longrightarrow} \mathrm{A}_{n+m}^{\prime \prime} & (m, n>1) \\
\mathrm{B}_{n}^{\prime \prime}+\mathrm{B}_{m}^{\prime \prime} \stackrel{4 k_{\mathrm{t}}}{\longrightarrow} \mathrm{B}_{n+m}^{\prime \prime} & (m, n>1)
\end{array}
$$

Shema 1 - Reakcijski mehanizam radikalskih polimerizacija uz monoperoksidni i diperoksidni inicijator Scheme 1 - Reaction mechanism of radical polymerization with mono- and di-peroxide initiator 
cijatora koji sadrže dvije peroksidne skupine, ili više njih, različite toplinske stabilnosti. Primjenom takvih inicijatora tijekom procesa polimerizacije dolazi i do naknadnog stvaranja (makro)radikala, čime je omogućena ponovna inicijacija, to jest reinicijacija makromolekulskih vrsta nastalih u ranijim stupnjevima procesa. Prethodna istraživanja pokazala su da je praktična prednost upotrebe takvih inicijatora proizvodnja polimera velikih molekulskih masa razmjerno uske raspodjele i, važno je napomenuti, visoke do potpune konverzije monomera. Količina ostatnoga, neizreagiranog monomera u polimerima uvijek je važan čimbenik zbog utjecaja na fizikalna svojstva materijala, ali i zakonom propisanih graničnih vrijednosti. Također, vrijeme reakcije može se znatno smanjiti bez potrebe mijenjanja reaktorskog sustava. ${ }^{20-22}$ Istovrsne ili slične prednosti nije moguće postići s uobičajenim monofunkcijskim radikalskim inicijatorima ili upotrebom njihovih mješavina. Reakcijski mehanizam odvijanja radikalskih polimerizacija uz monoperoksidni i diperoksidni inicijator prikazan je na shemi 1, a njihov opis kao i razvijeni kinetički modeli za oba slučaja detaljno su obrađeni u preglednom radu. ${ }^{23}$ Zbog visoke razine složenosti reakcijskog mehanizma polimerizacije i osobito kopolimerizacije u sustavima iniciranim višefunkcijskim peroksidnim inicijatorima (vidi shemu 1), klasično analitičko modeliranje i programiranje vrlo je često nepraktično i neprovedivo zbog velikog broja diferencijalnih jednadžbi i parametara modela koji se ne mogu eksperimentalno odrediti. Ipak, suvremeni koncepti i računalna podrška u velikoj mjeri olakšavaju krajnjem korisniku pronalaženje optimalnih procesnih uvjeta kao i provedbu parametarske analize s ciljem predviđanja i dobivanja molekulske građe polimera koja bi zadovoljila željena svojstva krajnjeg proizvoda kao što su mehanička, toplinska ili reološka svojstva.

U ovome radu glavni ciljevi bili su istražiti i unaprijediti proces proizvodnje polistirena $u$ otopini upotrebom difunkcijskog peroksidnog inicijatora, kao i strukturno-primjenska svojstva sintetiziranih polimera. ${ }^{24-30} \mathrm{U}$ tu svrhu provedena je dinamička simulacija rada polimerizacijskog šaržnog reaktora primjenom programskog sustava ChemCAD v. 5.4. (2004.), točnije njegova integriranog modula CC-Polymer. ${ }^{31}$ Taj programski paket primjenjuje teorijski postavljene kinetičke modele za izračun konverzije monomera te predviđanje osnovnih strukturnih svojstava polimera kao što su prosjeci i raspodjela molekulskih masa. Također je provedena i parametarska analiza (engl. sensitivity study) za ispitivane sustave s ciljem utvrđivanja utjecaja koncentracije monomera, koncentracije inicijatora, temperature i vremena reakcije na brzinu reakcije polimerizacije, odnosno konverziju monomera i glavna strukturna svojstva polimera. ${ }^{32}$ Modeliranje je provedeno za radikalsku homopolimerizaciju stirena u otopini ksilena za dvije različite koncentracije monomera od 3 i $5 \mathrm{~mol} \mathrm{dm}^{-3}$, uz difunkcijski peroksidni inicijator, u izotermnim uvjetima i do visokih konverzija monomera. Sintetiziranim homopolimerima određeni su brojčani $\left(M_{n}\right)$ i maseni $\left(M_{w}\right)$ prosjeci i raspodjela molarnih masa kromatografijom isključenja po veličini (SEC/GPC). Dobiveni rezultati vremenske ovisnosti konverzije i strukturnih svojstava polimera uspoređeni su s istim homopolimerizacijskim sustavom iniciranim s monofunkcijskim peroksidnim inicijatorom.

\section{Eksperimentalni dio Materijali}

Monomer primijenjen za sintezu, stiren (99,5 \%, čistoće za polimerizaciju, DIOKI Zagreb) propušten je kroz kolonu punjenu aluminijevim oksidom, pri sobnoj temperaturi i atmosferskom tlaku kako bi se uklonili inhibitori polimerizacije. Peroksidni inicijatori, monofukcijski: tert-butil-peroksi-2-etilheksanoat, komercijalnog naziva Trigonox $21^{\circledR}$ (otopina u mineralnom organskom otapalu, $w=70$ \%, Akzo Chemie) i difunkcijski: 1,1-di(tert-butilperoksi)-3,3,5-trimetilcikloheksan, komercijalnog naziva Trigonox $29^{\circledR}$ (otopina u dibutil-ftalatu, $w=90 \%$ otopina, Akzo Chemie) ${ }^{33-35}$ rabljeni su bez daljnjeg pročišćavanja kao i otapala ksilen, tetrahidrofuran i metanol (p. a.),

\section{Homopolimerizacija stirena}

Reakcije homopolimerizacije stirena u otopini ksilena provedene su u šaržnom kotlastom reaktoru obujma $0,5 \mathrm{dm}^{3} \mathrm{~s}$ plaštem za grijanje i hlađenje spojenim na protočni termostat s uljnom kupelji, pod atmosferom dušika i uz stalno miješanje reakcijske smjese $s$ pomoću mehaničke miješalice (sidrasto mješalo, 250 okretaja u minuti). Za kontrolu temperature u reaktoru primijenjeni su temperaturno osjetilo i termometar u uljnoj kupelji. Eksperimenti su provedeni do visokih konverzija monomera i u izotermnim uvjetima. Uzorci pripravljeni polimerizacijom u ksilenu istaloženi su u metanolu, a polimer je izdvojen dekantiranjem nakon čega je sušen u vakuumskom sušioniku do stalne mase. $U$ procesima polimerizacije, monofunkcijski peroksidni inicijator dodavan je reakcijskoj smjesi u četiri jednaka obroka (modificirani šaržni postupak): na samom početku reakcije te nakon 1, 2 i 4 sata trajanja reakcije. Cilj je bio postizanje veće djelotvornosti inicijatora i što veće konverzije monomera. Proces polimerizacije uz difunkcijski peroksidni inicijator proveden je potpuno šaržnim postupkom, odnosno inicijator je dodan reakcijskoj smjesi jednokratno na početku reakcije.

\section{Temperatura reakcije}

Za postizanje maksimalnog iskorištenja i dosega reakcije polimerizacije bilo je potrebno odabrati temperaturu reakcije pri kojoj će razgradnja peroksidnih skupina inicijatora biti optimalna, ali i usporediva između dvaju primijenjenih inicijatora (vidi sliku 1). Za svaki inicijator odabrane su dvije temperature. Poznavanjem vrijednosti Arrheniusove konstante $(A)$ i aktivacijske energije $\left(E_{a}\right)$ za svaki inicijator (dani od proizvođača), izračunata je brzina razgradnje odnosno promjena koncentracije inicijatora [I] s trajanjem reakcije $t$ prema izrazu:

$$
[]_{\mathrm{t}}=[\mathrm{I}]_{0} \exp \left(k_{\mathrm{d}} t\right),
$$

gdje je $k_{\mathrm{d}}$ konstanta razgradnje za monofunkcijski peroksidni inicijator, a izražava se kao funkcija temperature $T$ i opće plinske konstante $R$ prema sljedećem izrazu: ${ }^{33,34}$

$$
k_{\mathrm{d}} / \mathrm{s}^{-1}=1,54 \cdot 10^{14} \exp [-124900 /(R T)],
$$

dok je za difunkcijski peroksidni inicijator koji posjeduje dvije peroksidne skupine različite toplinske stabilnosti za proračun uzeta konstanta razgradnje $\left(k_{\mathrm{d}}\right)$ koja je dobivena 
za ukupnu razgradnju obiju peroksidnih skupina: ${ }^{33,35}$

$$
k_{\mathrm{d}} / \mathrm{s}^{-1}=7,59 \cdot 10^{13} \exp [-127520 /(R T)] .
$$

Prema dobivenim rezultatima, koji su prikazani na slici 1 , može se vidjeti da je pri temperaturi $100{ }^{\circ} \mathrm{C}$ za monofunkcijski i $105^{\circ} \mathrm{C}$ za difunkcijski inicijator brzina dekompozicije obaju inicijatora usporediva, a vrijeme poluraspada inicijatora, $t_{1 / 2}$ iznosi oko 1 sat. Pri drugim dvjema odabranim temperaturama, $105{ }^{\circ} \mathrm{C}$ za monofunkcijski i $115^{\circ} \mathrm{C}$ za difunkcijski, vrijeme poluraspada navedenih inicijatora, $t_{1 / 2}$ iznosi oko $20 \mathrm{~min}$.

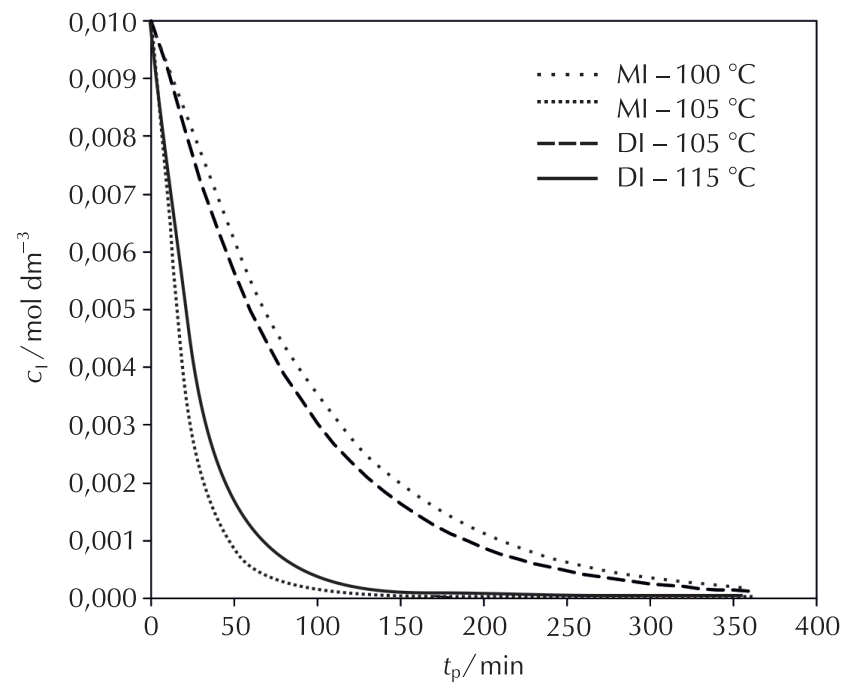

Slika 1 - Ovisnost koncentracije inicijatora $\left(c_{1}\right)$ o vremenu reakcije polimerizacije $\left(t_{\mathrm{p}}\right)$ pri dvjema različitim temperaturama za obje vrste inicijatora

Fig. 1 - Dependence of concentration of initiator $\left(c_{1}\right)$ on the polymerization reaction time $\left(t_{\mathrm{p}}\right)$ at two different temperatures for both types of initiators

\section{Koncentracija monomera i sastav reakcijske smjese}

Homopolimerizacija stirena u otopini ksilena provedena je pri dvjema različitim koncentracijama difunkcijskog peroksidnog inicijatora: 0,025 i $0,050 \mathrm{~mol} \mathrm{dm}^{-3}$. Niža koncentracija inicijatora $\left(0,025 \mathrm{~mol} \mathrm{dm}^{-3}\right)$ odabrana je radi usporedbe $s$ rezultatima dobivenima primjenom monoperoksidnog inicijatora pri dvostruko većoj koncentraciji $\left(0,05 \mathrm{~mol} \mathrm{dm}^{-3}\right)$. Naime, diperoksidni inicijator posjeduje dvije peroksidne skupine različite toplinske stabilnosti te bi u idealnom slučaju i pri potpunoj djelotvornosti inicijatora ukupna koncentracija primarnih radikala bila usporediva s koncentracijom monoperoksidnog inicijatora od $0,05 \mathrm{~mol} \mathrm{dm}^{-3}$. Ipak, s obzirom na to da djelotvornost inicijatora gotovo nikad nije potpuna $(f<1)$, eksperimenti uz difunkcijski peroksidni inicijator provedeni su i pri $0,050 \mathrm{~mol} \mathrm{dm}^{-3}$. Pregledan prikaz sastava reakcijske smjese i reakcijskih uvjeta provedenih polimerizacijskih eksperimenata dan je u tablici 1.

\section{Određivanje raspodjele molarnih masa polimera}

Određivanje raspodjele molarnih masa sintetiziranih polimera provedeno je metodom kromatografije isključenja po veličini (engl. Size Exclusion Chromatography, SEC). Mjerenja su provedena na kromatografskom uređaju PL-GPC 20 opremljenom diferencijalnim refraktometrijskim osjetilom (RI). Brzina protjecanja tetrahidofurana (THF), koji je upotrijebljen kao otapalo i eluens kroz kromatografski sustav, bila je $1 \mathrm{~cm}^{3} \mathrm{~min}^{-1}$. Mjerenja su provedena pri sobnoj temperaturi, a za preračunavanje obujma eluiranja u molarnu masu primijenjena je baždarna krivulja dobivena iz deset uzoraka polistirena vrlo uske raspodjele u rasponu molarnih masa od 580 do $377400 \mathrm{~g} \mathrm{~mol}^{-1}$ (PL PS-1B EasyCal).

\section{Dinamička simulacija rada šaržnog reaktora}

Primjenom programskog sustava za simuliranje procesa ChemCAD ${ }^{\circledR}$ v. 5.4. (2004.), točnije njegova integriranog modula CC-Polymer, provedena je dinamička simulacija rada polimerizacijskog šaržnog reaktora za proces homoplimerizacije stirena u otopini. ${ }^{31}$ CC-Polymer je potprogram koji omogućava provođenje dinamičke simulacije rada kotlastih, protočno-kotlastih i kontinuiranih polimerizacijskih reaktora. Uz to pruža uvid u cijeli niz primjenskih svojstava koja karakteriziraju dobiveni polimer. Jedna od najvećih prednosti upotrebe takvog softverskog paketa je što omogućava procesnom inženjeru da na vrlo prikladan način dimenzionira i detaljno ispita rad polimerizacijskih

Tablica 1 - Pregledni prikaz provedenih homopolimerizacijskih eksperimenata i pripadajućih reakcijskih uvjeta, te njihovih oznaka

Table 1 - Compilation of homopolymerization conducted experiments and associated reaction conditions, and their labels

\begin{tabular}{|c|c|c|c|c|}
\hline $\begin{array}{l}\text { Vrsta inicijatora } \\
\text { Initiator type }\end{array}$ & $c_{10} / \mathrm{mol} \mathrm{dm}^{-3}$ & $\vartheta /{ }^{\circ} \mathrm{C}$ & $C_{\mathrm{M} 0} / \mathrm{mol} \mathrm{dm}^{-3}$ & $\begin{array}{l}\text { Oznaka pokusa } \\
\text { Experiment label }\end{array}$ \\
\hline \multirow{5}{*}{$\begin{array}{l}\text { Difunkcijski } \\
\text { Bifunctional } \\
\text { (Trigonox 29) }\end{array}$} & \multirow{4}{*}{0,025} & \multirow{2}{*}{105} & 3 & DI-105-3 \\
\hline & & & 5 & Dl-105-5 \\
\hline & & \multirow{2}{*}{115} & 3 & DI-115-3 \\
\hline & & & 5 & DI-115-5A \\
\hline & 0,050 & 105 & 5 & DI-105-5B \\
\hline \multirow{4}{*}{$\begin{array}{l}\text { Monofunkcijski } \\
\text { Monofunctional } \\
\text { (Trigonox 21) }\end{array}$} & \multirow{4}{*}{0,050} & \multirow{2}{*}{105} & 3 & MI-105-3 \\
\hline & & & 5 & MI-105-5 \\
\hline & & \multirow{2}{*}{100} & 3 & MI-100-3 \\
\hline & & & 5 & MI-100-5 \\
\hline
\end{tabular}


reaktora kao i primjenska svojstva dobivenih proizvoda. CC-Polymer može se primijeniti i za analizu rada industrijskih i laboratorijskih polimerizacijskih reaktora te analizu eksperimentalnih podataka radi utvrđivanja odnosa između procesnih varijabli i primjenskih svojstava dobivenih polimera, što može biti od velike važnosti za razumijevanje reakcijskog mehanizma. Također, može se primijeniti i za analizu i utvrđivanje strategije reguliranja rada polimerizacijskog reaktora kao i vođenja procesa.

\section{Rezultati i rasprava}

\section{Usporedba eksperimentalnih i simulacijom dobivenih rezultata za proces homopolimerizacije stirena u otopini}

Slobodno-radikalske homopolimerizacije stirena provedene su u otopini ksilena uz difunkcijski peroksidni inicijator, u izotermnim uvjetima i do visokih konverzija monomera. Istražen je utjecaj koncentracije monomera, $C_{M}$, koncentracije inicijatora, $C_{1}$, reakcijske temperature, $T$, i vremena reakcije, $t_{\mathrm{p}}$, na brzinu reakcije polimerizacije odnosno konverziju monomera, $X$, te na glavna strukturna svojstva polimera. Dobiveni rezultati uspoređeni su s analognim homopolimerizacijskim sustavima gdje je inicijacija provedena uporabom monofunkcijskog peroksidnog inicijatora. Sintetiziranim homopolimerima stirena određena je raspodjela molarnih masa, brojčani i maseni prosjeci molarnih masa, $M_{\mathrm{n}}$ i $M_{\mathrm{w}}$ te disperznost, $\emptyset$, kao glavni strukturni parametri. Eksperimentalni rezultati uspoređeni su i s rezultatima dobivenima primjenom programske podrške za simuliranje procesa CC-Polymer u sklopu kojeg je provedena dinamička simulacija rada polimerizacijskog šaržnog reaktora. Program primjenjuje kinetički model radikalske polimerizacije ${ }^{23}$ za izračun konverzije monomera, a omogućava i predviđanje ranije spomenutih osnovnih strukturnih svojstava polimera u ovisnosti o vremenu reakcije i procesnim uvjetima: koncentraciji monomera, vrsti i koncentraciji inicijatora te temperaturi reakcije. S ciljem što boljeg definiranja polimerizacijskog sustava u sklopu modula CC-Polymer, nužno je kreirati vrlo detaljnu i opsežnu bazu podataka koja se odnosi na sve komponente odnosno kemijske vrste koje sudjeluju u reakciji homopolimerizacije. Tako su za monofunkcijski peroksidni inicijator, tert-butil-peroksi-2-etilheksanoat, difunkcijski peroksidni inicijator, 1,1-di(tert-butilperoksi)-3,3,5-trimetilcikloheksan, monomer, koji je u ovom slučaju bio stiren, živući polimerni radikal i polimer unijeti sljedeći podatci: najvažniji fizikalno-kemijski parametri kao što su molekulska masa, kritični tlak, kritična temperatura, vrelište, talište, parametri topljivosti, parametri za preračunavanje gustoće, toplinski kapacitet, viskoznost, parametri za preračunavanje tlaka para, sve funkcijske skupine i skupni doprinosi modela UNIFAC nužni za termodinamičke proračune. Nakon što je kreirana baza podataka svih komponenata koje sudjeluju u reakciji, bilo je potrebno definirati i vrstu polimerizacijskog procesa prema mediju provođenja reakcije (polimerizacija u masi ili otopini) te reakcijskom mehanizmu i kinetici reakcije (radikalska ili stupnjevita polimerizacija) te unijeti stvarne dimenzije reaktora u kojemu su provedeni eksperimenti. Nakon toga zadane su inicijalne vrijednosti procesnih varijabli kao što su početna temperatura, tlak, koncentracija inicijatora i koncentracija monomera. De- finirani su i određeni kinetički parametri procesa; u literaturi su dostupne vrijednosti konstanti propagacije $\left(k_{\mathrm{p}}\right) \mathrm{i}$ terminacije $\left(k_{\mathrm{t}}\right)$ za homopolimerizaciju stirena u masi ${ }^{20,25,36}$, dok su vrijednosti konstanti razgradnje $\left(k_{\mathrm{d}}\right)$ za inicijatore dani od proizvođača. Jedina ugodiva veličina bila je djelotvornost inicijatora, koja je postavljena u programu kao konstantna vrijednost. To se može smatrati jednim od nedostataka provedene računalne simulacije jer se u realnom procesu djelotvornost inicijatora može znatno mijenjati s vremenom reakcije. $U$ oba ispitana sustava djelotvornost inicijatora određena je računski traženjem najmanjeg srednjeg kvadratnog odstupanja između eksperimentalno $\left(X_{\text {eksp }}\right)$ i teorijski $\left(X_{\text {teor }}\right)$ dobivenih vrijednosti konverzije monomera u završnoj točki reakcije $\left(t_{\mathrm{p}}=6 \mathrm{~h}\right)$ prema jednadžbi:

$$
\min S^{2}=\left[\left(X_{\text {eksp }}-X_{\text {teor }}\right) / X_{\text {exp }}\right]^{2} \text {. }
$$

S obzirom da se ovdje radi o sekvencijalnoj dinamičkoj simulaciji, potrebno je specificirati i dinamičke postavke procesa. Empirijski, odabrano je vrijeme trajanja procesa od šest sati, a rezultati su se bilježili svakih 10 min. U nastavku, detaljno će biti prikazani i komentirani dobiveni rezultati.

Dodatno, dobro je poznato da je stiren monomer koji posjeduje mogućnost toplinske autoinicijacije, osobito pri temperaturama reakcije većim od $100{ }^{\circ} \mathrm{C}$. Eksperimenti toplinski autoinicirane homopolimerizacije stirena u ksilenu (5 $\mathrm{mol} \mathrm{dm}^{-3}$ ) pokazali su da je ostvarena konverzija stirena pri 105 i $115^{\circ} \mathrm{C}$ iznosila 17 , odnosno $26 \%$ za vrijeme reakcije od 6 sati (vidi sliku 2). Utjecaj toplinske inicijacije na konverziju monomera i strukturna svojstva polimera smanjuje se s dodatkom inicijatora i smanjenjem koncentracije stirena. Zbog pojednostavljenja nije posebno razmatran prilikom provedbe računalne simulacije procesa iako se ne može potpuno zanemariti pri svim ispitivanim uvjetima.

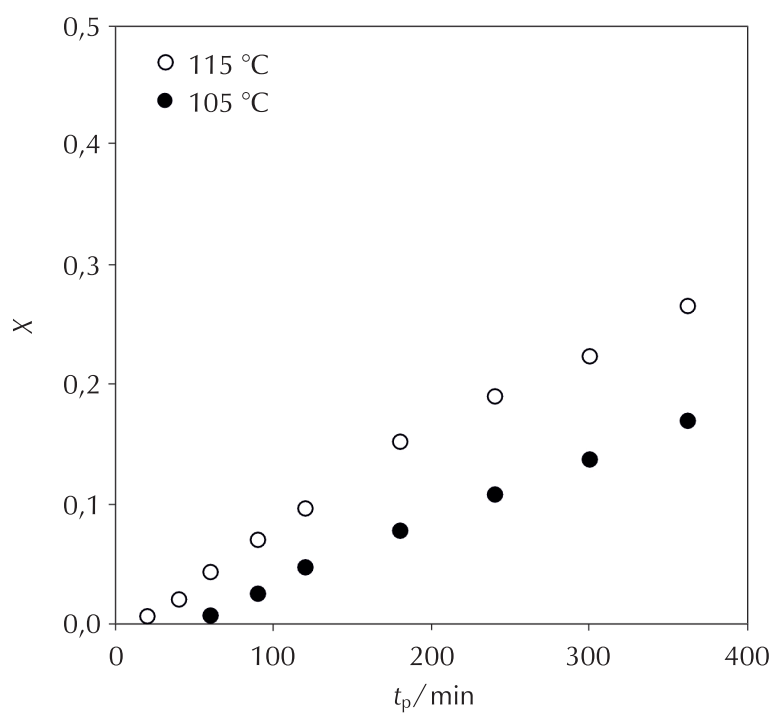

Slika 2 - Eksperimentalno dobivena ovisnost konverzije o vremenu za toplinski iniciranu homopolimerizaciju stirena u ksilenu pri 105 i $115^{\circ} \mathrm{C}$

Fig. 2 - Experimentally determined interdependence of the conversion and time for the thermally initiated homopolymerization of styrene in xylene solution at 105 and $115{ }^{\circ} \mathrm{C}$ 


\section{Homopolimerizacija stirena u otopini uz monofunkcijski peroksidni inicijator}

Na slikama od 3 do 8 uspoređeni su eksperimentalni i rezultati dobiveni simulacijom s pomoću modula CC-Polymer, za homopolimerizaciju stirena u ksilenu uz monofunkcijski inicijator. Parametri potrebni za računalnu simulaciju dani su u tablici 2.

Tablica 2 - Parametri za računalnu simulaciju homopolimerizacije stirena u otopini uz monofunkcijski peroksidni inicijator

Table 2 - Parameters used for computer simulation of the homopolymerization of styrene in xylene solution with monofunctional peroxide initiator

\begin{tabular}{|c|c|}
\hline $\begin{array}{l}\text { Veličina } \\
\text { Quantity }\end{array}$ & $\begin{array}{l}\text { Vrijednost } \\
\text { Value }\end{array}$ \\
\hline$k_{\mathrm{d}}$ & $1,54 \cdot 10^{14} \exp (-124900 / R T) \mathrm{s}^{-1}$ \\
\hline$k_{\mathrm{i}}$ & $1,05 \cdot 10^{7} \exp (-29500 / R T) \mathrm{dm}^{3} \mathrm{~mol}^{-1} \mathrm{~s}^{-1}$ \\
\hline$k_{\mathrm{p}}$ & $1,05 \cdot 10^{7} \exp (-29500 / R T) \mathrm{dm}^{3} \mathrm{~mol}^{-1} \mathrm{~s}^{-1}$ \\
\hline$k_{\mathrm{t} 0}$ & $1,23 \cdot 10^{9} \exp (-7020 / R T) \mathrm{dm}^{3} \mathrm{~mol}^{-1} \mathrm{~s}^{-1}$ \\
\hline$A_{1}$ & $2,57-5,05 \cdot 10^{-3} \mathrm{~T} / \mathrm{K}$ \\
\hline$A_{2}$ & $9,56-1,76 \cdot 10^{-2} \mathrm{~T} / \mathrm{K}$ \\
\hline$A_{3}$ & $-3,03+7,85 \cdot 10^{-3} \mathrm{~T} / \mathrm{K}$ \\
\hline$C_{\mathrm{M} 0}$ & 3,$0 ; 5,0 \mathrm{~mol} \mathrm{dm}^{-3}$ \\
\hline$C_{10}$ & $0,05 \mathrm{~mol} \mathrm{dm}^{-3}$ \\
\hline$f$ & $\begin{array}{l}\text { ugodiva veličina } \\
\text { adjustable value }\end{array}$ \\
\hline$\vartheta$ & $100,0{ }^{\circ} \mathrm{C} ; 105,0{ }^{\circ} \mathrm{C}$ \\
\hline$p$ & 1,0 bar \\
\hline$M_{1}$ & $216,3 \mathrm{~g} \mathrm{~mol}^{-1}$ \\
\hline$M_{\mathrm{ST}}$ & $104,2 \mathrm{~g} \mathrm{~mol}^{-1}$ \\
\hline$V_{R}$ & $650,0 \mathrm{~cm}^{3}$ \\
\hline$d$ & $10,0 \mathrm{~cm}$ \\
\hline
\end{tabular}

Na slikama 3 i 4 prikazana je ovisnost konverzije monomera o vremenu reakcije polimerizacije provedene pri temperaturama $100{ }^{\circ} \mathrm{C} \mathrm{i} 105{ }^{\circ} \mathrm{C}$, koncentracijama monomera $3 \mathrm{~mol} \mathrm{dm}^{-3}$ i $5 \mathrm{~mol} \mathrm{dm}^{-3}$, i jednoj koncentraciji inicijatora $0,05 \mathrm{~mol} \mathrm{dm}^{-3}$. Može se vidjeti u oba slučaja da s porastom koncentracije monomera raste i konverzija. S porastom temperature povećava se brzina reakcije, ali dolazi i do izraženog trošenja inicijatora u prvih sat vremena reakcije, što rezultira pojavom platoa, odnosno stagnacijom konverzije s obzirom na vrijeme trajanja reakcije. Vidljivi blagi porast konverzije monomera pri duljim vremenima i odstupanje od simulacijski dobivenih konverzijskih platoa, osobito za polimerizacije pri višoj temperaturi, može biti posljedica toplinske autoinicijacije monomera. Završne konverzije monomera su male i ne prelaze $50 \%$, a djelotvornost inicijatora je vrlo mala - simulacijom je dobivena vrijednost od samo 0,15. Dodatno, prema obliku krivulja konverzija-vrijeme može se zaključiti da ne dolazi do po- jave samoubrzanja procesa polimerizacije (gel-efekt) koja se javlja zbog smanjenja brzine terminacije uzrokovane fizikalnom (difuzijskom) kontrolom reakcije zbog povećanja viskoznosti reakcijske mase. ${ }^{2}$

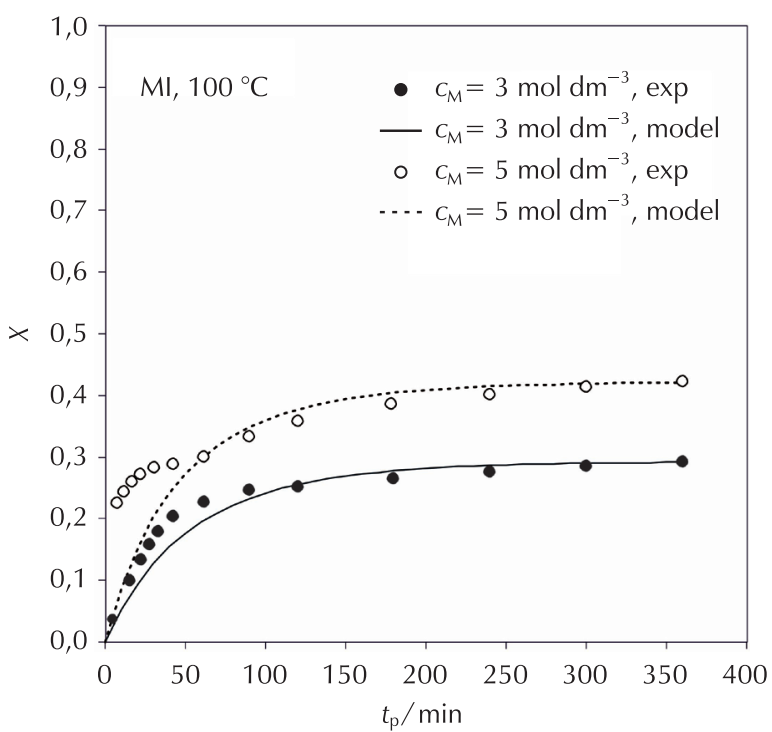

Slika 3 - Eksperimentalno (simboli) i simulacijski (linije) dobivena ovisnost konverzije o vremenu za homopolimerizaciju stirena u otopini uz monofunkcijski inicijator pri $100^{\circ} \mathrm{C} i$ koncentracijama monomera 3,0 i 5,0 $\mathrm{mol} \mathrm{dm}^{-3}$

Fig. 3 - Experimentally obtained (symbols) and simulated (lines) interdependence of the conversion on time for the solution homopolymerization of styrene with the monofunctional initiator at $100{ }^{\circ} \mathrm{C}$ and the concentration of monomers: 3.0 and $5.0 \mathrm{~mol} \mathrm{dm}^{-3}$

Iz prikazanih rezultata može se vidjeti da je bolje slaganje eksperminentalnih i simulacijskih rezultata postignuto za sustav s nižom koncentracijom monomera. Najveće odstupanje od modela i to u oba slučaja može se primijetiti u prvom satu provedbe reakcije. To se može objasniti prethodno spomenutim ograničenjem provedene računalne simulacije gdje se koeficijent djelotvornosti inicijatora $(f)$ definira kao nepromjenjiva veličina. Naime, glavni uzročnik niske djelotvornosti inicijatora je mehanizam rekombinacije primarnih radikala (zbog čega ne dolazi do reakcije inicijacije s monomerom) što se naziva efektom kaveza. Kada se inicijator raspadne, nastali primarni radikali najbliži su jedan drugom u vremenu od oko $10^{-10}$ do $10^{-9}$ s. Tijekom tog intervala, primarni radikali su okruženi tj. zatočeni u "kavezu" molekula otapala kroz koje moraju difundirati kako bi inicirali reakciju polimerizacije. Zbog nestabilnosti, vrijeme života radikala je vrlo kratko, velika je vjerojatnost reakcije izravne rekombinacije radikala, čime može nastati originalna molekula inicijatora, a može doći i do drugih reakcija koje ne stvaraju polimerni lanac. ${ }^{6,25}$ Nadalje, kao što je ranije napomenuto, konverzija stirena zbog toplinske inicijacije nije uzeta u obzir, kao niti reakcije prijenosa rasta lanca, osobito na monomer i otapalo. Ipak, važno je ovdje istaknuti da je, unatoč lošijem slaganju u početku reakcije polimerizacije, pri završetku reakcije slaganje eksperimentalnih rezultata s modelom razmjerno zadovoljavajuće u oba ispitana slučaja. 


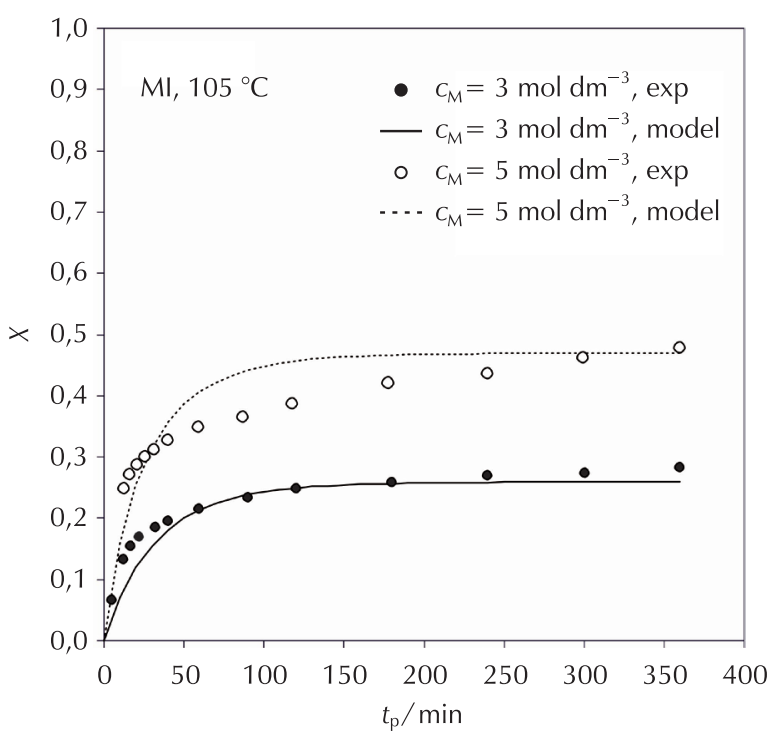

Slika 4 - Eksperimentalno (simboli) i simulacijski (linije) dobivena ovisnost konverzije o vremenu za homopolimerizaciju stirena u otopini uz monofunkcijski inicijator pri $105{ }^{\circ} \mathrm{C}$ i koncentracijama monomera 3,0 i 5,0 mol dm$^{-3}$

Fig. 4 - Experimentally obtained (symbols) and simulated (lines) interdependence of the conversion on time for the solution homopolymerization of styrene with the monofunctional initiator at $105{ }^{\circ} \mathrm{C}$ and the concentration of monomers: 3.0 and $5.0 \mathrm{~mol} \mathrm{dm}^{-3}$

Na slikama od 5 do 8 prikazana je ovisnost eksperimentalno i simulacijski dobivenih brojčanih $\left(M_{n}\right)$ i masenih $\left(M_{w}\right)$ prosjeka molarnih masa polistirena o vremenu reakcije polimerizacije, koje su provedene pri temperaturama od $100{ }^{\circ} \mathrm{C}$ i $105{ }^{\circ} \mathrm{C}$, koncentracijama monomera od $3 \mathrm{~mol} \mathrm{dm}^{-3}$ i $5 \mathrm{~mol} \mathrm{dm}^{-3}$ i koncentraciji inicijatora $0,05 \mathrm{~mol} \mathrm{dm}^{-3}$. Sukladno kinetici radikalskih polimerizacija, molarne mase $\left(M_{n}, M_{w}\right)$ polistirena rastu s povećanjem koncentracije monomera $\left(C_{M}\right)$ u reakcijskoj smjesi. ${ }^{2,24}$ Također, iz dobivenih rezultata vidi se da porast temperature reakcije od $5{ }^{\circ} \mathrm{C}$ nema veći utjecaj na konačne mase, s obzirom na to da su se vrijednosti prosjeka molarnih masa tek neznatno smanjile: $M_{\mathrm{n}, \text { eksp }}\left(\mathrm{MI}, 3 \mathrm{~mol} \mathrm{dm}^{-3}, 100{ }^{\circ} \mathrm{C}\right)=8776 \mathrm{~g} \mathrm{~mol}^{-1}$; $M_{\text {n,eksp }}\left(\mathrm{Ml}, 3 \mathrm{~mol} \mathrm{dm}^{-3}, 105{ }^{\circ} \mathrm{C}\right)=8761 \mathrm{~g} \mathrm{~mol}^{-1} ; M_{\text {n,eksp }}$ (MI, $\left.5 \mathrm{~mol} \mathrm{dm}^{-3}, 100{ }^{\circ} \mathrm{C}\right)=15863 \mathrm{~g} \mathrm{~mol}^{-1} ; M_{\mathrm{n}, \text { eksp }}(\mathrm{MI}, 5$ mol dm $\left.{ }^{-3}, 105^{\circ} \mathrm{C}\right)=14433 \mathrm{~g} \mathrm{~mol}^{-1}$. Modelom predviđene vrijednosti prosjeka molarnih masa $\left(M_{n}\right)$ većinom se znatno razlikuju od eksperimentalno određenih. Glavni razlozi tih odstupanja su već prethodno spomenuti djelotvornost inicijatora, utjecaj toplinske inicijacije i reakcija prijenosa rasta lanca koje nisu uzete u obzir prilikom provedbe računalne simulacije. ${ }^{25}$

Također, znatnoj razlici eksperimentalno i simulacijski određenih vrijednosti molarnih masa može doprinijeti i konstanta terminacije $\left(k_{\mathrm{t}}\right)$ primijenjena prilikom provedbe računalne simulacije, čija je vrijednost preuzeta iz literature. ${ }^{20}$ Naime, razvoj izraza za $k_{\mathrm{t}}$ tijekom cijelog procesa polimerizacije vrlo je složen. Stoga se često primjenjuje empirijski pristup te se vrijednost $k_{\mathrm{t}}$ opisuje sljedećim izrazom:

$$
k_{\mathrm{t}}=k_{\mathrm{t} 0} \exp \left[-\left(A_{1} X+A_{2} X^{2}+A_{3} X^{3}\right)\right],
$$

gdje je $X$ konverzija monomera, $k_{\mathrm{t} 0}$ konstanta reakcije ter- minacije pri konverziji $=0$, a $A_{1}, A_{2}$ i $A_{3}$ su ugodivi parametri. Ti su parametri funkcije temperature i koncentracije inicijatora, a određuju se iz krivulje konverzija-vrijeme $(X-t)$. Tako određena vrijednost $k_{\mathrm{t}}$ ne uzima u obzir kinetičku duljinu lanca pa stoga nije odgovarajuća za sve radikalske vrste koji sudjeluju u reakciji.

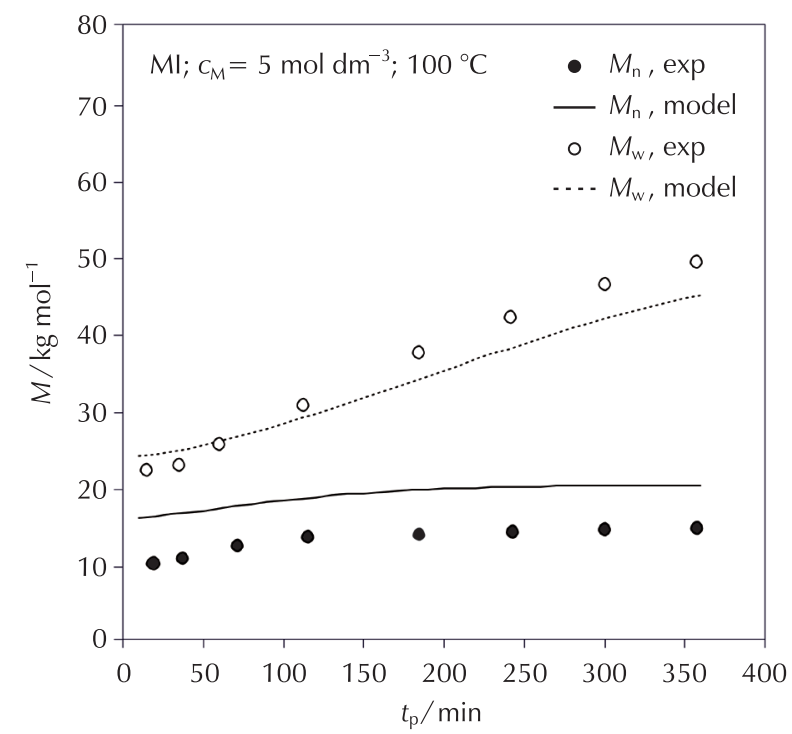

Slika 5 - Ovisnost brojčanog $\left(M_{\mathrm{n}}\right)$ i masenog $\left(M_{\mathrm{w}}\right)$ prosjeka molarnih masa o vremenu polimerizacije inicirane monofunkcijskim inicijatorom, pri temperaturi reakcije $100{ }^{\circ} \mathrm{C}$ i koncentraciji monomera 3,0 $\mathrm{mol} \mathrm{dm}^{-3}$

Fig. 5 - Dependence of number $\left(M_{n}\right)$ and weight $\left(M_{w}\right)$ average molar mass on the reaction time for polymerization initiated with monofunctional initiator at temperature of $100{ }^{\circ} \mathrm{C}$ and monomer concentration of $3.0 \mathrm{~mol} \mathrm{dm}^{-3}$

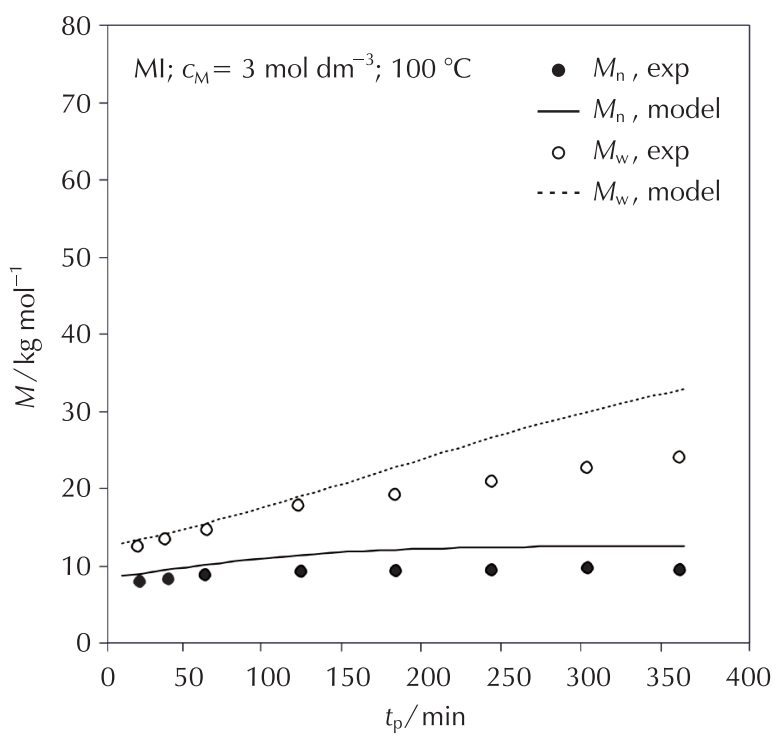

Slika 6 - Ovisnost brojčanog $\left(M_{\mathrm{n}}\right)$ i masenog $\left(M_{\mathrm{w}}\right)$ prosjeka molarnih masa o vremenu polimerizacije inicirane monofunkcijskim inicijatorom, pri temperaturi reakcije $100{ }^{\circ} \mathrm{C}$ i koncentraciji monomera 5,0 $\mathrm{mol} \mathrm{dm}^{-3}$

Fig. 6 - Dependence of number $\left(M_{n}\right)$ and weight $\left(M_{w}\right)$ average molar mass on the reaction time for polymerization initiated with monofunctional initiator at temperature of $100{ }^{\circ} \mathrm{C}$ and monomer concentration of $5.0 \mathrm{~mol} \mathrm{dm}^{-3}$ 
Eksperimentalno određene vrijednosti masenih i brojčanih prosjeka molarnih masa rastu s vremenom reakcije odnosno s porastom konverzije monomera. Nerazmjerni rast prosjeka masa uzrokuje širenje raspodjele masa, odnosno povećanje disperznosti $(\bigoplus)$, a isti trend dobiven je i simuliranjem ispitanih sustava.

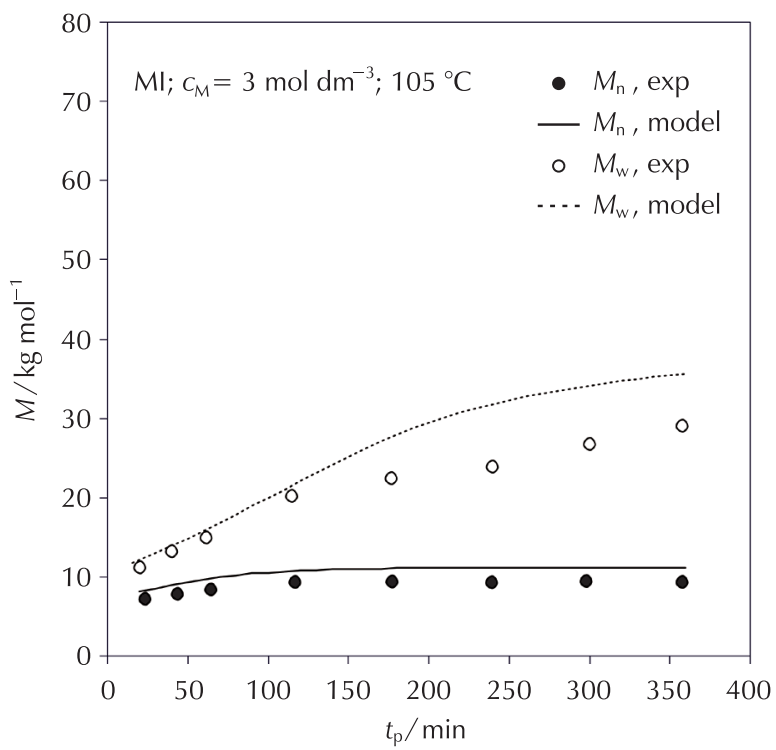

Slika 7 - Ovisnost brojčanog $\left(M_{n}\right)$ i masenog $\left(M_{w}\right)$ prosjeka molarnih masa o vremenu polimerizacije inicirane monofunkcijskim inicijatorom, pri temperaturi reakcije 105 ${ }^{\circ} \mathrm{C}$ i koncentraciji monomera 3,0 $\mathrm{mol} \mathrm{dm}^{-3}$

Fig. 7 - Dependence of number $\left(M_{n}\right)$ and weight $\left(M_{w}\right)$ average molar mass on the reaction time for polymerization initiated with monofunctional initiator at temperature of $105{ }^{\circ} \mathrm{C}$ and monomer concentration of $3.0 \mathrm{~mol} \mathrm{dm}^{-3}$

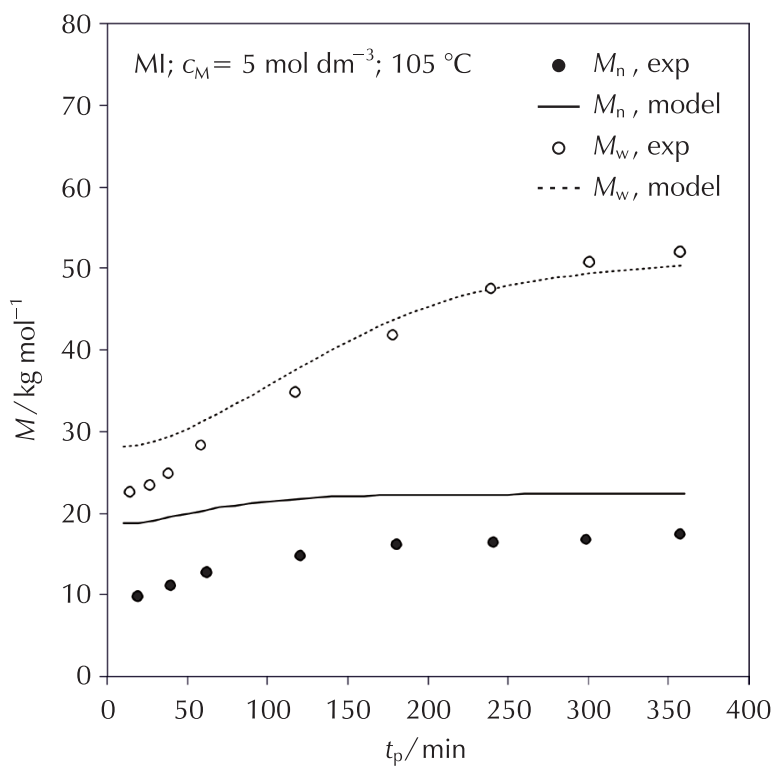

Slika 8 - Ovisnost brojčanog $\left(M_{\mathrm{n}}\right)$ i masenog $\left(M_{\mathrm{w}}\right)$ prosjeka molarnih masa o vremenu polimerizacije inicirane monofunkcijskim inicijatorom, pri temperaturi reakcije $105{ }^{\circ} \mathrm{C}$ i koncentraciji monomera 5,0 $\mathrm{mol} \mathrm{dm}^{-3}$

Fig. 8 - Dependence of number $\left(M_{n}\right)$ and weight $\left(M_{w}\right)$ average molar mass on the reaction time for polymerization initiated with monofunctional initiator at temperature of $105^{\circ} \mathrm{C}$ and monomer concentration of $5.0 \mathrm{~mol} \mathrm{dm}^{-3}$

\section{Homopolimerizacija stirena u otopini uz difunkcijski peroksidni inicijator}

Eksperimentalni rezultati dobiveni za homopolimerizaciju stirena u otopini ksilena uz difunkcijski inicijator uspoređeni su s onima dobivenim simulacijski s pomoću programskog modula CC-Polymer. Parametri upotrijebljeni za računalnu simulaciju dani su u tablici 3. Budući da modul ne sadrži kinetički model polimerizacije uz difunkcijski inicijator, simulacija je obavljena tako da je difunkcijski inicijator opisan kao dva monofunkcijska inicijatora, svaki sa svojom konstantom dekompozicije ${ }^{36}$ (vidi tablicu 3) ili to zahtijeva određenu eksternu prilagodbu modula.

Tablica 3 - Parametri za računalnu simulaciju homopolimerizacije stirena u otopini ksilena uz difunkcijski peroksidni inicijator

Table 3 - Parameters used for computer simulation of the homopolymerization of styrene in xylene solution with bifunctional peroxide initiator

\begin{tabular}{|c|c|}
\hline $\begin{array}{l}\text { Veličina } \\
\text { Quantity }\end{array}$ & $\begin{array}{l}\text { Vrijednost } \\
\text { Value }\end{array}$ \\
\hline$k_{\mathrm{d} 1}$ & $7,59 \cdot 10^{13} \exp (-127520 / R T) \mathrm{s}^{-1}$ \\
\hline$k_{\mathrm{d} 2}$ & $6,42 \cdot 10^{18} \exp (-167293 / R T) \mathrm{s}^{-1}$ \\
\hline$k_{\mathrm{i}}$ & $1,05 \cdot 10^{7} \exp (-29500 / R T) \mathrm{dm}^{3} \mathrm{~mol}^{-1} \mathrm{~s}^{-1}$ \\
\hline$k_{\mathrm{p}}$ & $1,05 \cdot 10^{7} \exp (-29500 / R T) \mathrm{dm}^{3} \mathrm{~mol}^{-1} \mathrm{~s}^{-1}$ \\
\hline$k_{\mathrm{t} 0}$ & $1,23 \cdot 10^{9} \exp (-7020 / R T) \mathrm{dm}^{3} \mathrm{~mol}^{-1} \mathrm{~s}^{-1}$ \\
\hline$A_{1}$ & $2,57-5,05 \cdot 10^{-3} \mathrm{~T} / \mathrm{K}$ \\
\hline$A_{2}$ & $9,56-1,76 \cdot 10^{-2} \mathrm{~T} / \mathrm{K}$ \\
\hline$A_{3}$ & $-3,03+7,85 \cdot 10^{-3} \mathrm{~T} / \mathrm{K}$ \\
\hline$C_{M 0}$ & $5,0 \mathrm{~mol} \mathrm{dm}^{-3}$ \\
\hline$C_{10}$ & $0,025 \mathrm{~mol} \mathrm{dm}^{-3} ; 0,05 \mathrm{~mol} \mathrm{dm}^{-3}$ \\
\hline$f$ & $\begin{array}{ll}0,45 & \text { ugodiva veličina } \\
\text { adjustable value }\end{array}$ \\
\hline$\vartheta$ & $105,0{ }^{\circ} \mathrm{C} ; 115,0{ }^{\circ} \mathrm{C}$ \\
\hline$p$ & 1,0 bar \\
\hline$M_{1}$ & $302,4 \mathrm{~g} \mathrm{~mol}^{-1}$ \\
\hline$M_{\mathrm{ST}}$ & $104,2 \mathrm{~g} \mathrm{~mol}^{-1}$ \\
\hline$V_{\mathrm{R}}$ & $650,0 \mathrm{~cm}^{3}$ \\
\hline$d$ & $10,0 \mathrm{~cm}$ \\
\hline
\end{tabular}

Na slikama od 9 do 11 prikazana je ovisnost konverzije monomera o vremenu reakcije za homopolimerizacije provedene pri temperaturama $105{ }^{\circ} \mathrm{C} \mathrm{i} 115{ }^{\circ} \mathrm{C}$, za dvije različite koncentracije inicijatora $0,025 \mathrm{~mol} \mathrm{dm}^{-3}$ i $0,05 \mathrm{~mol} \mathrm{dm}^{-3}$ i uz koncentraciju monomera $5,0 \mathrm{~mol} \mathrm{dm}^{-3}$. Može se vidjeti da su u odnosu na sustave inicirane monofunkcijskim inicijatorom postignute znatno veće konverzije monomera i to pri dvostruko manjoj koncentraciji inicijatora od 0,025 mol $\mathrm{dm}^{-3}$. Razlog tome je mehanizam raspada difunkcijskog inicijatora u kojem dolazi do naknadnog stvaranja radikala, čime se omogućava ponovna inicijacija (reinicijacija) (vidi shemu 2). Takvim mehanizmom dobiva se ravnomjerniji 
<smiles>CCCCOC1(OOC(C)(C)C)CCCCC1OOC(C)(C)C</smiles>

Shema 2 - Mehanizam dekompozicije difunkcijskog peroksidnog inicijatora Scheme 2 - Decomposition mechanism of bifunctional peroxide initiator

odnos između koncentracije nastalih radikala i neizreagiranog monomera, a time i veća djelotvornost inicijatora, što je i računski potvrđeno $(f=0,45)$. Toplinska stabilnost peroksidnih skupina monofunkcijskog inicijatora jednaka je i raspad se odvija jednovremeno za sve skupine, dok difunkcijski inicijator koji sadrži dvije peroksidne skupine gdje se raspada prvo jedna (shema 2: vrste I, II, III), a zatim druga peroksidna skupina (shema 2: vrste IV, II, V), pa je i ukupna koncentracija nastalih radikala ravnomjernije raspoređena s vremenom. ${ }^{27}$

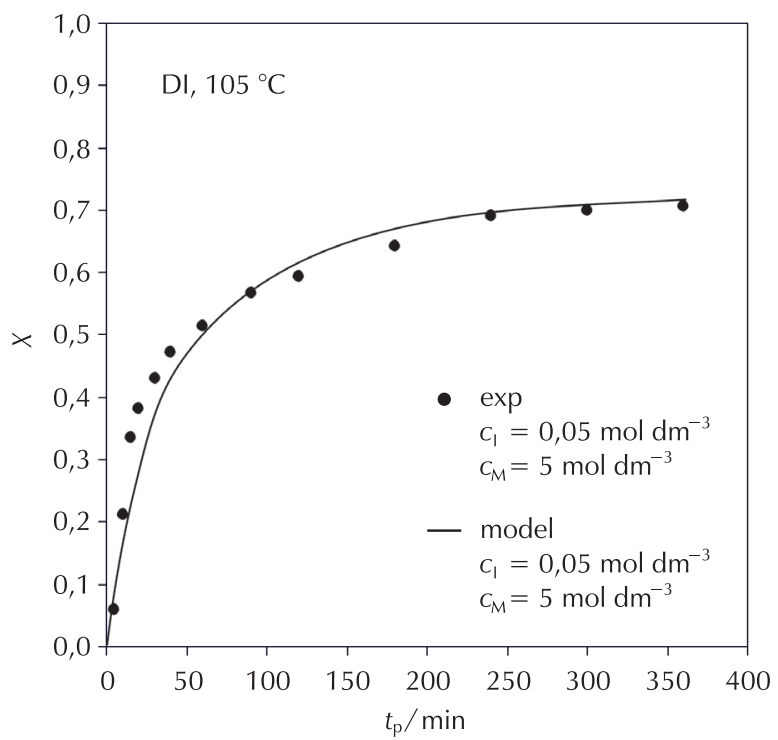

Slika 9 - Eksperimentalno (simboli) i simulacijski (linije) dobivena ovisnost konverzije o vremenu za homopolimerizaciju stirena u otopini uz difunkcijski inicijator koncentracije $0,05 \mathrm{~mol} \mathrm{dm}^{-3}$ pri $105^{\circ} \mathrm{C}$

Fig. 9 - Experimentally obtained (symbols) and simulated (lines) interdependence of conversion on reaction time for the homopolymerization of styrene in a solution with a bifunctional initiator concentration of $0.05 \mathrm{~mol} \mathrm{dm}^{-3}$ at $105^{\circ} \mathrm{C}$

Također, iz dobivenih eksperimentalnih rezultata može se vidjeti da povišenjem temperature reakcije od $10{ }^{\circ} \mathrm{C}$ očekivano dolazi do veće brzine reakcije, posebno u prvih
60 - 120 minuta, a nakon toga se konverzija monomera malo mijenja s vremenom reakcije (vidi sliku 11). Do toga dolazi jer je u tom vremenu nastaje najveća količina slobodnih radikala, slično kao i kod polimerizacija iniciranih monoperoksidnim inicijatorom.

Uspoređujući eksperimentalne i simulacijski dobivene rezultate vremenske ovisnosti konverzije monomera, može se vidjeti razmjerno dobro slaganje za cijelo vrijeme reakcije homopolimerizacije u odnosu na iste sustave inicirane monofunkcijskim inicijatorom. Stoga se može reći da prilagođeni kinetički model uz dvije konstante dekompozicije inicijatora vrlo dobro opisuje realno stanje procesa homopolimerizacije stirena u otopini uz difunkcijski inicijator.

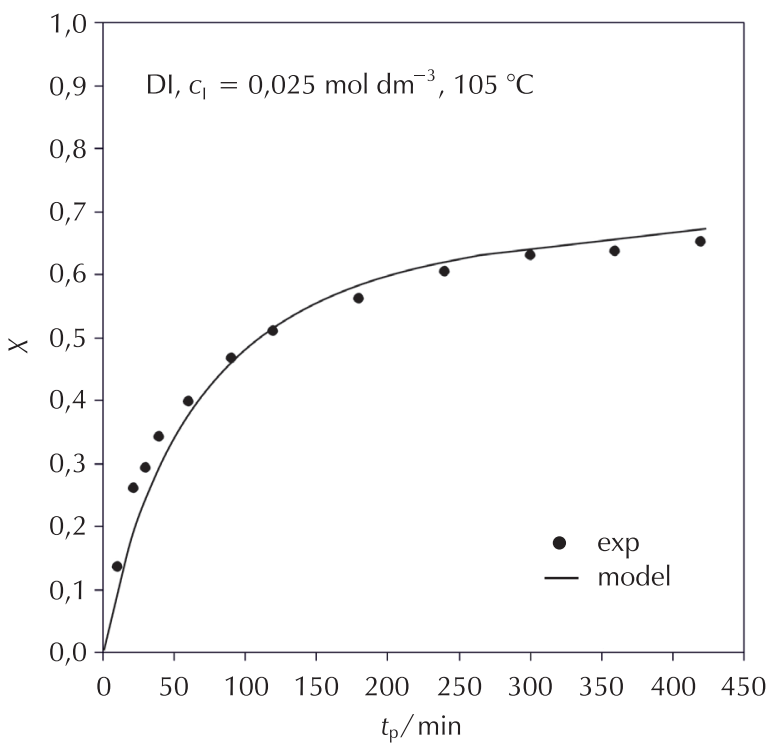

Slika 10 - Eksperimentalno (simboli) i simulacijski (linije) dobivena ovisnost konverzije o vremenu za homopolimerizaciju stirena u otopini uz difunkcijski inicijator koncentracije $0,025 \mathrm{~mol} \mathrm{dm}^{-3}$ pri $105^{\circ} \mathrm{C}$

Fig. 10 - Experimentally obtained (symbols) and simulated (lines) interdependence of conversion on reaction time for the homopolymerization of styrene in a solution with a bifunctional initiator concentration of 0.025 mol dm ${ }^{-3}$ at $105{ }^{\circ} \mathrm{C}$ 


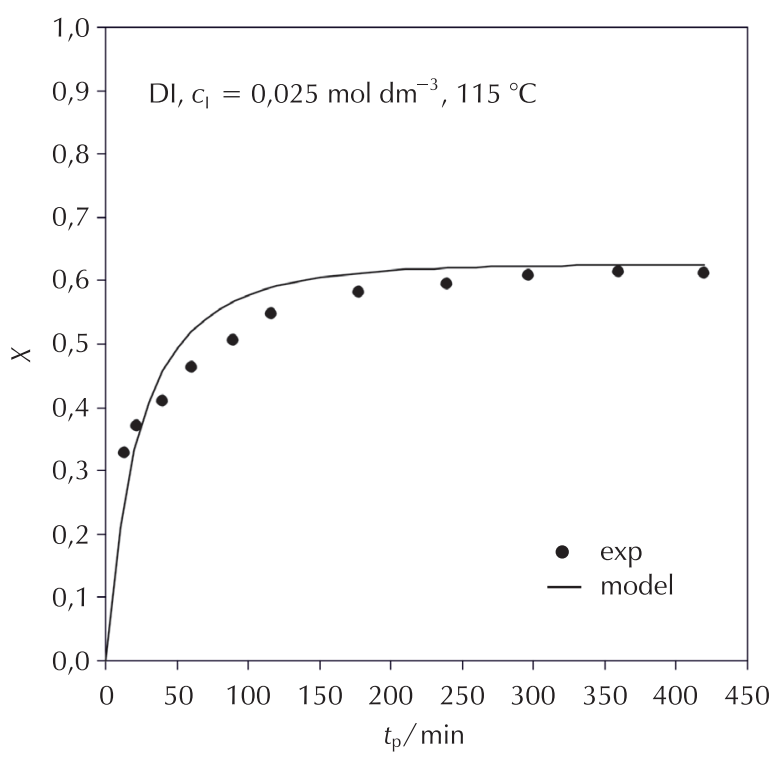

Slika 11 - Eksperimentalno (simboli) i simulacijski (linije) dobivena ovisnost konverzije o vremenu za homopolimerizaciju stirena u otopini uz difunkcijski inicijator koncentracije $0,025 \mathrm{~mol} \mathrm{dm}^{-3}$ pri $115^{\circ} \mathrm{C}$

Fig. 11 - Experimentally obtained (symbols) and simulated (lines) interdependence of conversion on reaction time for the homopolymerization of styrene in a solution with a bifunctional initiator concentration of $0.025 \mathrm{~mol} \mathrm{dm}^{-3}$ at $115{ }^{\circ} \mathrm{C}$

Na slikama od 12 do 14 prikazana je ovisnost eksperimentalno i simulacijski dobivenih brojčanih i masenih prosjeka molarnih masa o vremenu reakcije za polimerizacije provedene pri temperaturama od $105^{\circ} \mathrm{C}$ i $115^{\circ} \mathrm{C}$, pri dvjema koncentracijama inicijatora $0,025 \mathrm{~mol} \mathrm{dm}^{-3}$ i 0,05 mol $\mathrm{dm}^{-3}$ i koncentraciji monomera $5 \mathrm{~mol} \mathrm{dm}^{-3}$. Iz rezultata je vidljivo da su postignute vrijednosti prosjeka molarnih masa znatno veće u odnosu na one dobivene za sustave inicirane monoperoksidnim inicijatorom. Ova je činjenica od velikog primjenskog značaja s obzirom da su visoke vrijednosti molarnih masa, a posebno masenog prosjeka molarnih masa potrebne u primjeni kopolimera sa stirenom kao reoloških modifikatora mazivih ulja. ${ }^{37-39}$ Također, povišenje temperature reakcije od $10{ }^{\circ} \mathrm{C}$ nije znatno utjecalo na smanjenje vrijednosti molarnih masa što je još jedna od prednosti upotrebe diperoksidnog inicijatora u odnosu na monoperoksidni.

Simulacijom dobivene ovisnosti prosjeka molarnih masa o vremenu reakcije donekle prate trend dobiven eksperimentalnim određivanjima, pri čemu su odstupanja pri nižim konverzijama veća. Vrijednosti pri završnim konverzijama vrlo dobro se slažu, osobito za polimerizaciju provedenu pri $115{ }^{\circ} \mathrm{C}$. Modelom dobiveni prosjeci molarnih masa $\left(M_{n}\right.$ i $\left.M_{w}\right)$ veći su u odnosu na eksperimentalno određene. Razlozi zabilježenih odstupanja slični su kao i kod sustava s monofunkcijskim inicijatorom.

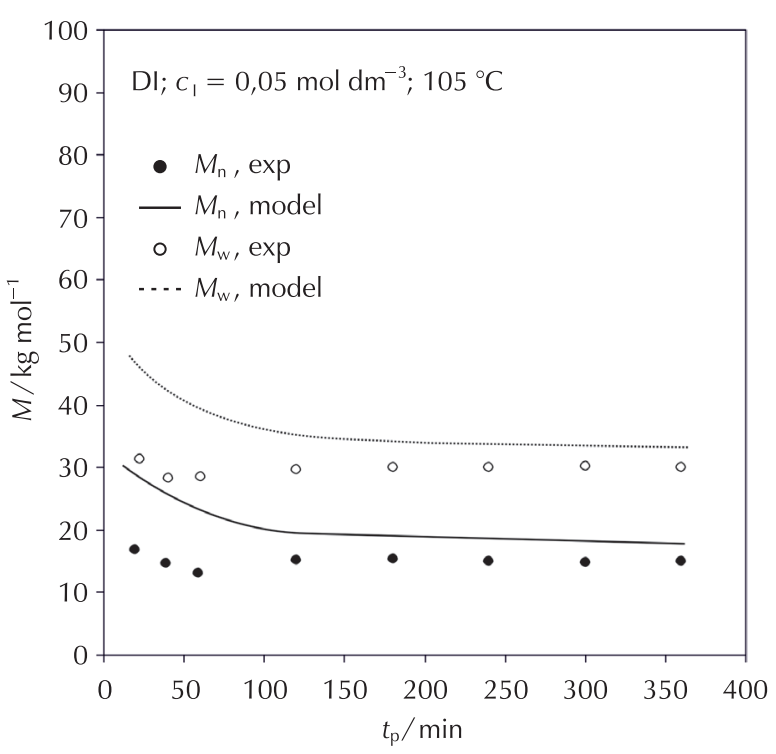

Slika 12 - Ovisnost brojčanog $\left(M_{\mathrm{n}}\right)$ i masenog $\left(M_{\mathrm{w}}\right)$ prosjeka molarnih masa o vremenu polimerizacije inicirane difunkcijskim inicijatorom, pri temperaturi reakcije $105^{\circ} \mathrm{C}$ i koncentraciji inicijatora $0,05 \mathrm{~mol} \mathrm{dm}^{-3}$

Fig. 12 - Dependence of number $\left(M_{n}\right)$ and weight $\left(M_{w}\right)$ average molar mass on the reaction time for polymerization initiated with bifunctional initiator at temperature of $105{ }^{\circ} \mathrm{C}$ and initiator concentration of $0.05 \mathrm{~mol} \mathrm{dm}^{-3}$

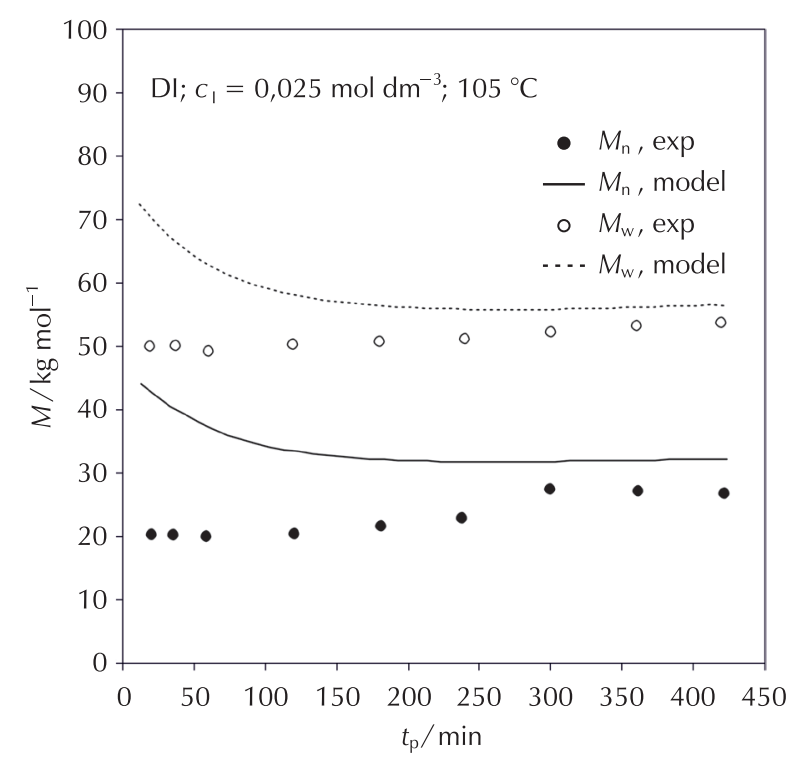

Slika 13 - Ovisnost brojčanog $\left(M_{n}\right)$ i masenog $\left(M_{w}\right)$ prosjeka molarnih masa o vremenu polimerizacije inicirane difunkcijskim inicijatorom, pri temperaturi reakcije $105{ }^{\circ} \mathrm{C}$ i koncentraciji inicijatora $0,025 \mathrm{~mol} \mathrm{dm}^{-3}$

Fig. 13 - Dependence of number $\left(M_{n}\right)$ and weight $\left(M_{w}\right)$ average molar mass on the reaction time for polymerization initiated with bifunctional initiator at temperature of $105{ }^{\circ} \mathrm{C}$ and initiator concentration of $0.025 \mathrm{~mol} \mathrm{dm}^{-3}$ 


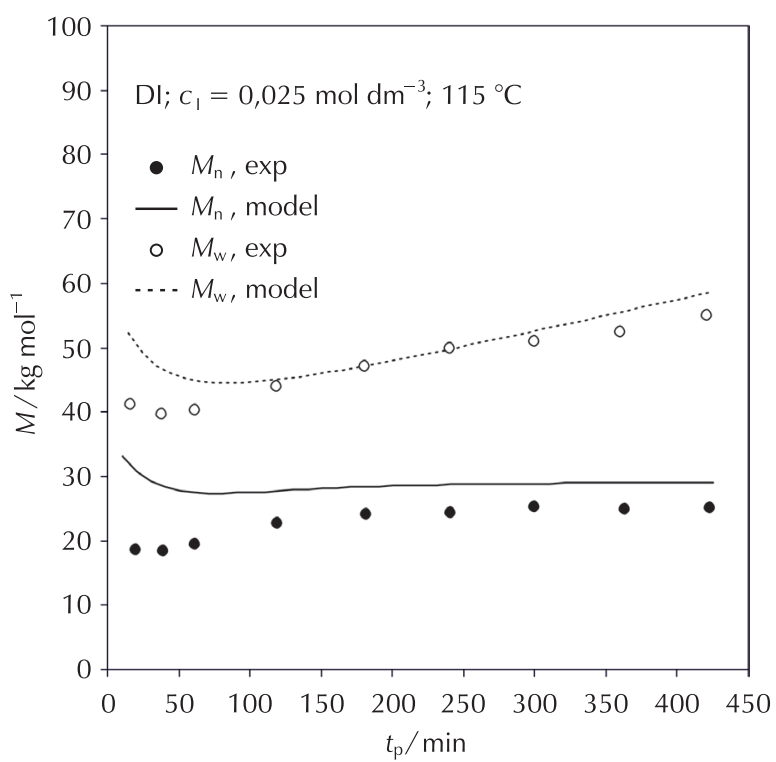

Slika 14 - Ovisnost brojčanog $\left(M_{n}\right)$ i masenog $\left(M_{w}\right)$ prosjeka molarnih masa o vremenu polimerizacije inicirane difunkcijskim inicijatorom, pri temperaturi reakcije $115{ }^{\circ} \mathrm{C}$ i koncentraciji inicijatora $0,025 \mathrm{~mol} \mathrm{dm}^{-3}$

Fig. 14 - Dependence of number $\left(M_{n}\right)$ and weight $\left(M_{w}\right)$ average molar mass on the reaction time for polymerization initiated with bifunctional initiator at temperature of $115^{\circ} \mathrm{C}$ and initiator concentration of $0.025 \mathrm{~mol} \mathrm{dm}^{-3}$

\section{Parametarska analiza}

S obzirom na dobivene eksperimentalne rezultate koji su potvrdili određene prednosti upotrebe difunkcijskog peroksidnog inicijatora za homopolimerizaciju stirena u otopini ksilena u odnosu na monoperoksidni, dodatno je provedena i parametarska analiza s ciljem utvrđivanja njegovih krajnjih primjenskih mogućnosti i maksimalne učinkovitosti postizanjem potpune konverzije monomera. ${ }^{39}$ Parametarska analiza provedena je upotrebom CC-Polymera, integriranog modula ChemCAD-a, specijaliziranog isključivo za proračun i analizu polimerizacijskih procesa, budući da su prethodno dobiveni simulacijski rezultati bili u razmjerno dobrom slaganju s eksperimentalnim podacima. Parametri primijenjeni za računalnu simulaciju dani su u tablici 3 .

Zadana su tri uvjeta u sklopu kojih je ispitan utjecaj temperature $(\vartheta)$ - uvjet 1 , koncentracije inicijatora $\left(C_{1}\right)$ - uvjet 2 , koncentracije monomera $\left(c_{M}\right)$ - uvjet 3 i vremena $\left(t_{\mathrm{p}}\right)$ na brzinu reakcije polimerizacije (konverziju monomera, $X$ ), odnosno količinu ostatnog monomera (ost. M), količinu ostatnog inicijatora (ost. I), glavna strukturna svojstva polimera kao što su brojčani i maseni prosjek molarnih masa $\left(M_{n}, M_{w}\right)$ i disperznost $(\Theta)$.

\section{Uvjet 1 - utjecaj temperature ( $९$ )}

$U$ prvom slučaju ispitan je utjecaj temperature na ostale procesne čimbenike s obzirom na to da je temperatura jedna od najvažnijih procesnih varijabli koje određuju dinamiku i učinkovitost cjelokupnog procesa. Njezinim povećanjem raste i brzina reakcije, ali istodobno dolazi i do smanjenja vrijednosti molarnih masa uz širenje njihove raspodjele (veći $\bigoplus$ ), što se može nepovoljno odraziti na krajnja primjenska svojstva sintetiziranih polimera. Vrijednosti temperature mijenjane su u koracima od $5{ }^{\circ} \mathrm{C}$ u rasponu od $95{ }^{\circ} \mathrm{C}$ do $125^{\circ} \mathrm{C}$, dok su ostale veličine držane pri konstantnim vrijednostima (tablica 4). Rezultati dobiveni simulacijom procesa homopolimerizacije stirena uz difunkcijski peroksidni inicijator uz prethodno zadane uvjete dani su u tablici 5. te prikazani na slikama od 15 do 17.

Tablica 4 - Uvjet 1 - utjecaj temperature $(T)$

Table 4 - Condition 1 - Effect of temperature $(T)$

\begin{tabular}{c|c|c|c}
\hline $9 /{ }^{\circ} \mathrm{C}$ & $\Delta T /{ }^{\circ} \mathrm{C}$ & $\mathrm{C}_{\mathrm{l}} / \mathrm{mol} \mathrm{dm}^{-3}$ & $\mathrm{C}_{\mathrm{M}} / \mathrm{mol} \mathrm{dm}^{-3}$ \\
\hline $95-125$ & 5 & 0,025 & 5,0
\end{tabular}

Tablica 5 - Rezultati dobiveni simulacijom procesa homopolimerizacije stirena uz difunkcijski peroksidni inicijator pri ispitivanju utjecaja temperature ( () na procesne i ostale veličine $\left(c_{M^{\prime}}, c_{1}, X, M_{n}, M_{w}, \oslash\right.$, ost. M, ost. I)

Table 5 - Results obtained by simulating the process of homopolymerization of styrene with bifunctional initiator - examining the effects of temperature $(\vartheta)$ on the process and other values $\left(c_{M}, c_{1}, X, M_{n}, M_{w}, \bigoplus\right.$, res. $M$, res. I)

\begin{tabular}{|c|c|c|c|c|c|c|c|}
\hline$\vartheta /{ }^{\circ} \mathrm{C}$ & 95 & 100 & 105 & 110 & 115 & 120 & 125 \\
\hline$X / \%$ & 64,51 & 68,83 & 70,32 & 69,07 & 65,96 & 62,16 & 58,32 \\
\hline$\oslash$ & 1,71 & 1,65 & 1,58 & 1,64 & 1,82 & 2,34 & 3,38 \\
\hline$M_{\mathrm{n}} / \mathrm{g} \mathrm{mol}^{-1}$ & 43278 & 37608 & 35276 & 34047 & 32468 & 30603 & 28701 \\
\hline$M_{\mathrm{w}} / \mathrm{g} \mathrm{mol}^{-1}$ & 72875 & 61948 & 55909 & 54573 & 58932 & 71516 & 97132 \\
\hline $\begin{array}{l}m(\text { ost. } M) / g \\
m(\text { res. } M) / g\end{array}$ & 85,63 & 76,41 & 74,62 & 79,62 & 88,5 & 98,5 & 108,5 \\
\hline $\begin{array}{l}m(\text { ost. l) } / \mathrm{g} \\
m(\text { res. l }) / g\end{array}$ & 0,85 & 0,27 & 0,04 & 0,001 & $7,3 \times 10^{-6}$ & $1,30 \times 10^{-9}$ & $1,30 \times 10^{-15}$ \\
\hline
\end{tabular}




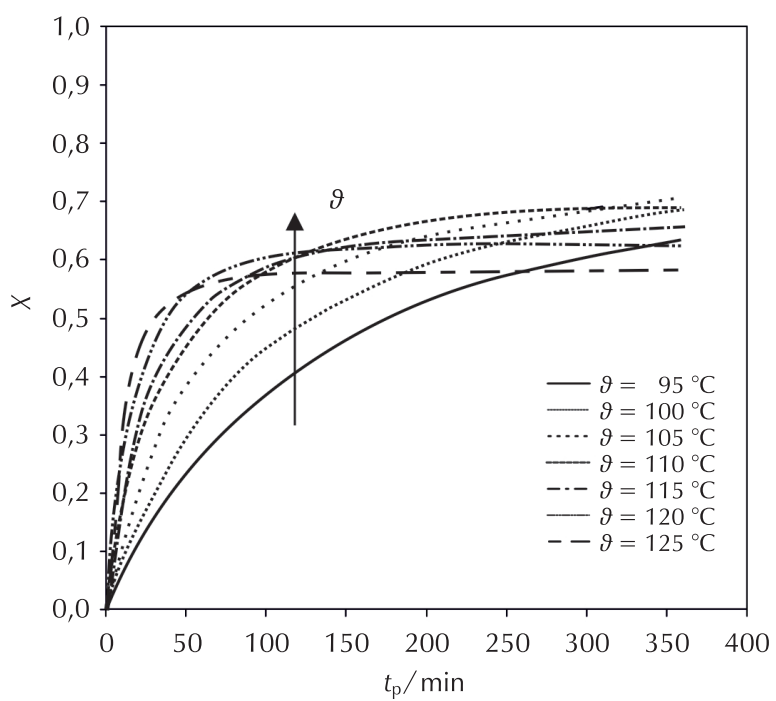

Slika 15 - Rezultati simulacije za ovisnost konverzije monomera o vremenu reakcije homopolimerizacije stirena uz difunkcijski peroksidni inicijator pri 95, 100, 105, 110, 115,120 i $125{ }^{\circ} \mathrm{C}$

Fig. 15 - Simulation results for the dependence of monomer conversion on reaction time for homopolymerization of styrene initiated with bifunctional initiator at 95, $100,105,110,115,120$, and $125^{\circ} \mathrm{C}$

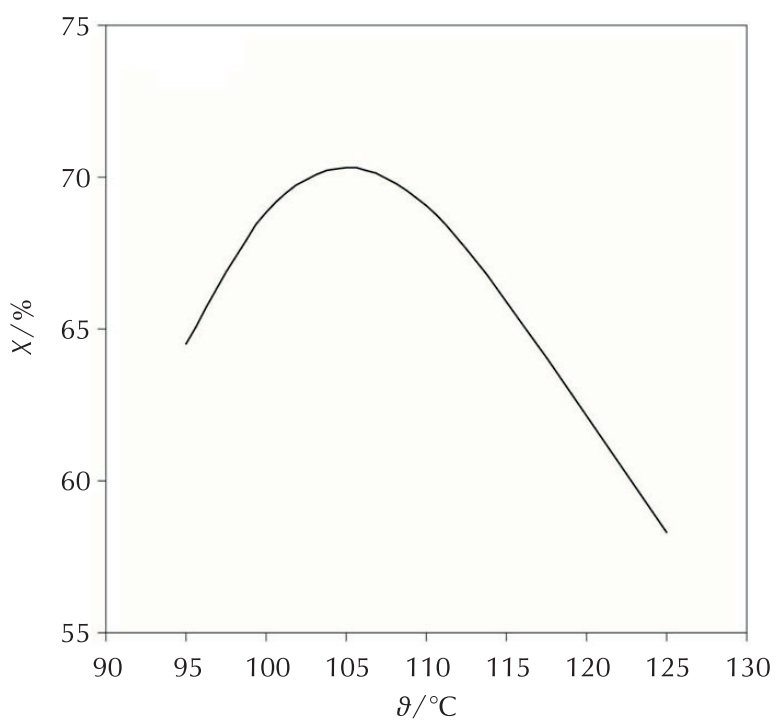

Slika 16 - Rezultati simulacije za utjecaj temperature reakcije $\left(95,100,105,110,115,120\right.$ i $\left.125^{\circ} \mathrm{C}\right)$ na maksimalnu konverziju monomera $(X)$ za ukupno vrijeme polimerizacije 6 sati

Fig. 16 - Simulation results for the influence of the reaction temperature $\left(95,100,105,110,115,120\right.$, and $\left.125^{\circ} \mathrm{C}\right)$ on maximum monomer conversion $(X)$ for polymerization time of 6 hours

Iz dobivenih rezultata (vidi slike 15 i 16) vidi se da s porastom temperature do $105{ }^{\circ} \mathrm{C}$ postupno rastu i brzina reakcije te konverzija monomera. Međutim, s daljnjim porastom temperature, zbog bržeg raspada inicijatora u prvim satima procesa i smanjenja njegove djelotvornosti, smanjuje se i konverzija monomera.

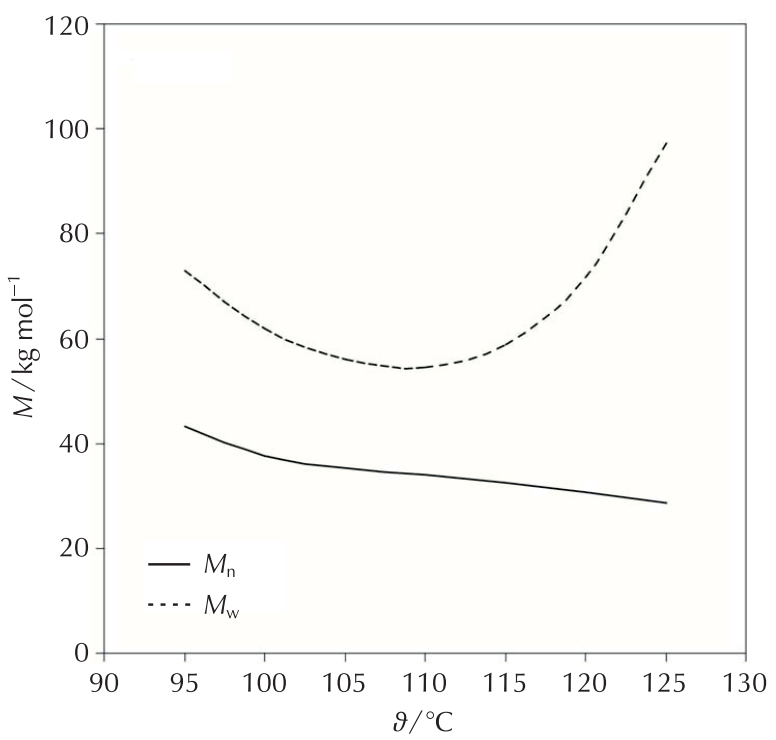

Slika 17 - Rezultati simulacije za utjecaj temperature reakcije (95, $100,105,110,115,120$ i $125^{\circ} \mathrm{C}$ ) na završne prosjeke molarnih masa za ukupno vrijeme polimerizacije od 6 sati

Fig. 17 - Simulation results for the influence of the reaction temperature $\left(95,100,105,110,115,120\right.$, and $\left.125^{\circ} \mathrm{C}\right)$ on the final average molar mass values for polymerization time of 6 hours

S porastom temperature prosječne vrijednosti molarnih masa smanjuje se sve do $105{ }^{\circ} \mathrm{C}$, kada dolazi do naglog porasta vrijednosti masenog prosjeka molarnih masa $\left(M_{w}\right)$, što izravno utječe na znatno povećanje disperznosti odnosno širinu raspodjele molarnih masa. Šira raspodjela i veće vrijednosti disperznosti pokazatelj su neoptimalno odabranih uvjeta koji rezultiraju dobivanjem polimera lošijih primjenskih mogućnosti.

\section{Uvjet 2 - utjecaj koncentracije inicijatora $\left(C_{1}\right)$}

$U$ drugom slučaju ispitan je utjecaj koncentracije inicijatora na procesne i ostale čimbenike s obzirom na to da količina inicijatora izravno utječe na vrijednosti molarnih masa, ali i ekonomičnost cjelokupnog procesa s obzirom i na njihovu visoku cijenu koštanja. Koncentracija (količina) inicijatora mijenjala se za $0,0125 \mathrm{~mol} \mathrm{dm}^{-3}(2 \mathrm{~g})$ u rasponu od 0,025 mol dm ${ }^{-3}(4 \mathrm{~g}) \mathrm{do} 0,140 \mathrm{~mol} \mathrm{dm}^{-3}(20 \mathrm{~g})$, dok su ostale procesne veličine držane pri konstantnim vrijednostima (tablica 6). Rezultati dobiveni simulacijom dani su u tablici 7 te su prikazani na slikama 18 i 19.

Tablica 6 - Uvjet 2 - utjecaj koncentracije inicijatora $\left(C_{1}\right)$

Table 6 - Condition 2 - effect of initiator concentration $\left(C_{1}\right)$

\begin{tabular}{c|c|c|c}
\hline$C_{1} / \mathrm{mol} \mathrm{dm}^{-3}$ & $\Delta c_{1} / \mathrm{mol} \mathrm{dm}^{-3}$ & $\vartheta /{ }^{\circ} \mathrm{C}$ & $C_{\mathrm{M}} / \mathrm{mol} \mathrm{dm}^{-3}$ \\
\hline $0,025-0,140$ & 0,0125 & 105 & 5,0 \\
\hline
\end{tabular}


Tablica 7 - Rezultati dobiveni simulacijom procesa homopolimerizacije stirena uz difunkcijski peroksidni inicijator pri ispitivanju utjecaja koncentracije (količine) inicijatora $\left(c_{1}, m_{1}\right)$ na procesne i ostale veličine $\left(c_{M}, \vartheta, X, M_{n}, M_{w}, \bigoplus\right.$, ost. M, ost. I)

Table 7 - Results obtained by simulating the process of homopolymerization of styrene with bifunctional initiator - examining the impact of the concentration (amount) of initiator $\left(c_{1}, m_{1}\right)$ on the process and other values $\left(c_{\mathrm{M}}, \vartheta, X, M_{\mathrm{n}}, M_{\mathrm{w}}, \bigoplus\right.$, res. $M$, res. I)

\begin{tabular}{|c|c|c|c|c|c|c|c|c|c|}
\hline$m_{1} / g$ & 4 & 6 & 8 & 10 & 12 & 14 & 16 & 18 & 20 \\
\hline$X / \%$ & 70,32 & 74,92 & 77,97 & 80,22 & 81,97 & 83,39 & 84,58 & 85,6 & 86,5 \\
\hline$\bigoplus$ & 1,58 & 1,65 & 1,72 & 1,78 & 1,84 & 1,9 & 1,96 & 2,01 & 2,05 \\
\hline$M_{\mathrm{n}} / \mathrm{g} \mathrm{mol}^{-1}$ & 35276 & 25057 & 19560 & 16098 & 13708 & 11953 & 10608 & 9542 & 8676 \\
\hline$M_{\mathrm{w}} / \mathrm{g} \mathrm{mol}^{-1}$ & 55909 & 41424 & 33638 & 28698 & 25247 & 22679 & 20683 & 19078 & 17755 \\
\hline $\begin{array}{l}m(\text { ost. M) } / g \\
m(\text { res. M }) / g\end{array}$ & 74,6 & 62,87 & 55,05 & 49,32 & 44,87 & 41,26 & 38,25 & 35,68 & 33,45 \\
\hline $\begin{array}{l}m(\text { ost. I) } / \mathrm{g} \\
m(\text { res. I) } / \mathrm{g}\end{array}$ & 0,04 & 0,057 & 0,077 & 0,096 & 0,115 & 0,134 & 0,153 & 0,172 & 0,192 \\
\hline
\end{tabular}

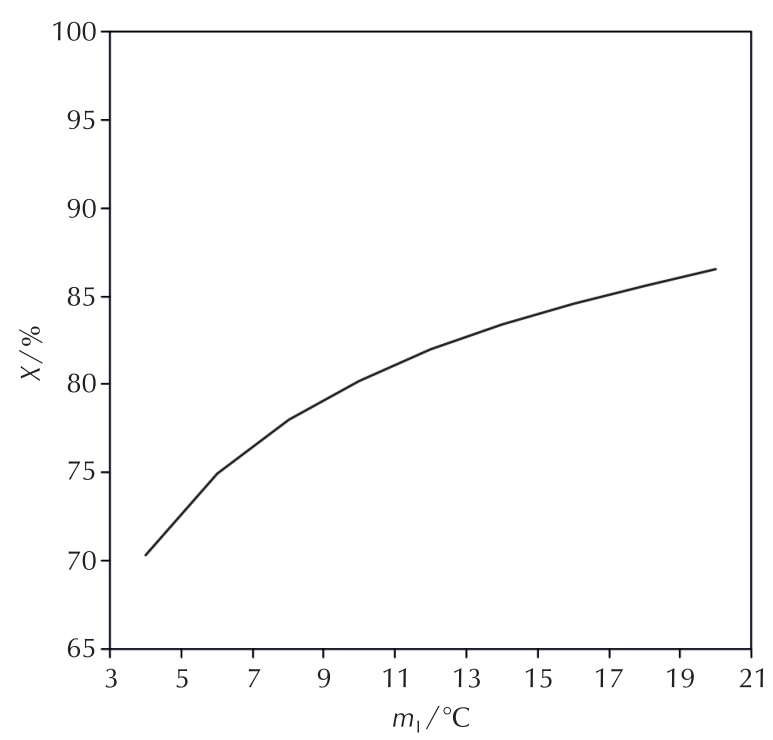

Slika 18 - Rezultati simulacije za utjecaj koncentracije inicijatora (iskazan masom, $m_{1}$ ) na konverziju monomera $(X)$

Fig. 18 - Simulation results for the effect of initiator concentration (expressed by mass, $m_{1}$ ) on monomer conversion $(X)$

Iz dobivenih rezultata vidljivo je da se s povećanjem koncentracije inicijatora i to za gotovo pet puta, konverzija monomera povećala svega oko $15 \%$; istodobno, prosjeci molarnih masa smanjili su se za gotovo tri $\left(M_{\mathrm{w}}\right)$ odnosno četiri puta $\left(M_{n}\right)$. Slijedi da je djelotvornost inicijatora za polimerizaciju stirena u otopini vrlo mala, dok povećanje njegove koncentracije povećava konverziju monomera, ali ne linearno.

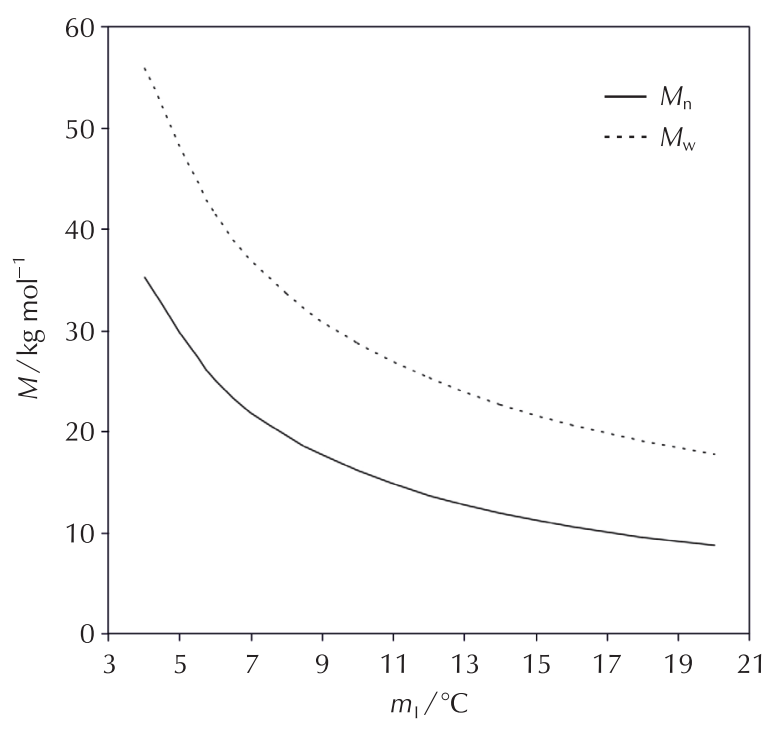

Slika 19 - Rezultati simulacije za utjecaj koncentracije inicijatora (iskazan masom, $m_{1}$ ) na završne prosjeke molarnih masa

Fig. 19 - Simulation results for the effect of initiator concentration (expressed by mass, $m_{1}$ ) on final average molar mass values

\section{Uvjet 3 - utjecaj koncentracije monomera $\left(c_{M}\right)$}

U trećem razmatranom slučaju ispitan je utjecaj koncentracije monomera na procesne i ostale čimbenike. Koncentracija monomera mijenjala se za $1 \mathrm{~mol} \mathrm{dm}^{-3} \mathrm{u}$ rasponu od $2 \mathrm{~mol} \mathrm{dm}^{-3}$ do $8 \mathrm{~mol} \mathrm{dm}^{-3}$, dok su ostale procesne veličine držane pri konstantnim vrijednostima (tablica 8.). Rezultati dobiveni simulacijom dani su u tablici 9 te prikazani na slikama 20 i 21. 
Tablica 8 - Uvjet 3 - utjecaj koncentracije monomera $\left(C_{\mathrm{M}}\right)$

Table 8 - Condition 3 - Effect of the monomer concentration $\left(c_{\mathrm{M}}\right)$

\begin{tabular}{c|c|c|c}
\hline$C_{\mathrm{M}} / \mathrm{mol} \mathrm{dm}^{-3}$ & $\Delta c_{\mathrm{M}} / \mathrm{mol} \mathrm{dm}^{-3}$ & $\vartheta /{ }^{\circ} \mathrm{C}$ & $\mathrm{C}_{\mathrm{l}} / \mathrm{mol} \mathrm{dm}^{-3}$ \\
\hline $2,0-8,0$ & 1,0 & 105 & 0,025 \\
\hline
\end{tabular}

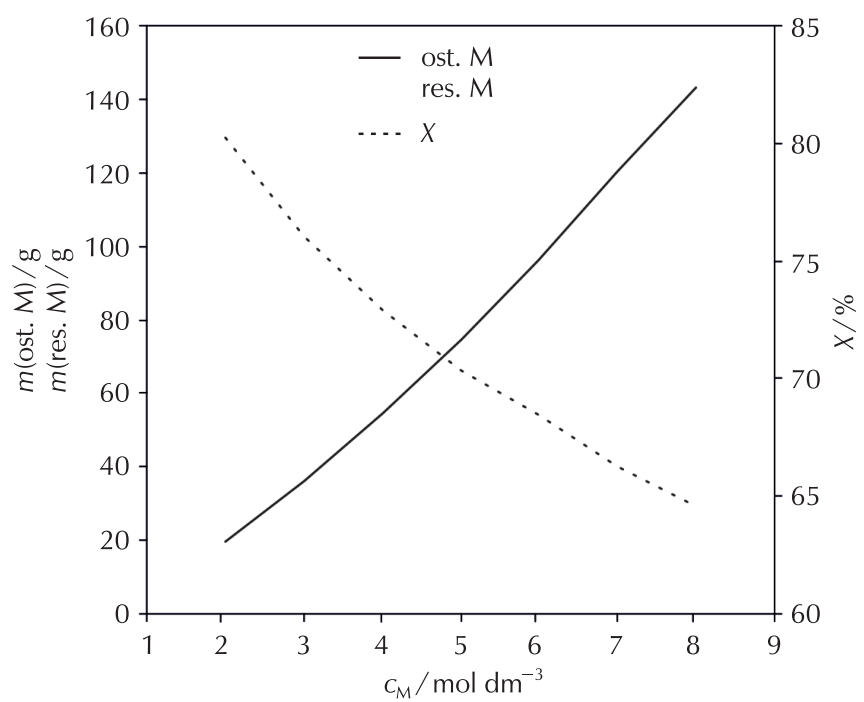

Slika 20 - Rezultati simulacije za utjecaj koncentracije monomera $\left(C_{M}\right)$ na konverziju monomera $(X)$ i masu ostatnog monomera, ost. $M$

Fig. 20 - Simulation results for the effect of monomer concentration) $\left(C_{\mathrm{M}}\right)$ on the conversion of monomer $(X)$ and residual monomer content, res. $\mathrm{M}$

Iz dobivenih rezultata (slika 20) može se vidjeti da s povećanjem koncentracije monomera, raste količina neizreagiranog monomera, odnosno smanjuje se konverzija $(X)$.

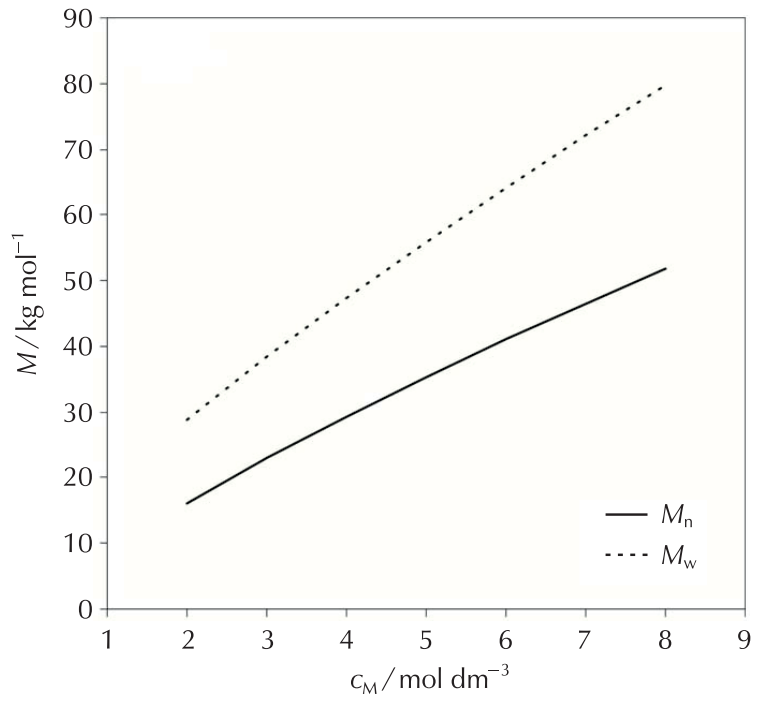

Slika 21 - Rezultati simulacije za utjecaj koncentracije monomera $\left(C_{\mathrm{M}}\right)$ na prosjeke molarnih masa

Fig. 21 - Simulation results for the effect of monomer concentration $\left(c_{M}\right)$ on the average molar mass values

Uzrok tome je neravnomjeran odnos između količine nastalih radikala i neizreagiranog monomera u reakcijskoj smjesi. Drugim riječima, iako povećavanjem koncentracije monomera rastu vrijednosti prosjeka molarnih masa (slika 21), ukupan doseg reakcije i učinkovitost cijelog procesa smanjuju se ako ne postoji optimalan odnos između količine monomera i inicijatora (radikalskih vrsta) u reakcijskoj smjesi.

Tablica 9 - Rezultati dobiveni simulacijom procesa homopolimerizacije stirena uz difunkcijski peroksidni inicijator pri ispitivanju utjecaja koncentracije monomera $\left(C_{M}\right)$ na procesne i ostale veličine $\left(c_{1}, \vartheta, X, M_{\mathrm{n}}, M_{\mathrm{w}}, \ominus\right.$, ost. $M$, ost. I)

Table 9 - Results obtained by simulating the process of homopolymerization of styrene with bifunctional initiator - examining the impact of monomer concentration $\left(C_{M}\right)$ on the process and other values $\left(c_{1}, \vartheta, X, M_{n}, M_{w}, \oslash\right.$, res. $M$, res. I)

\begin{tabular}{|c|c|c|c|c|c|c|c|}
\hline$C_{\mathrm{M}} / \mathrm{mol} \mathrm{dm}^{-3}$ & 2 & 3 & 4 & 5 & 6 & 7 & 8 \\
\hline$X / \%$ & 80,22 & 76,06 & 72,89 & 70,32 & 68,47 & 66,26 & 64,6 \\
\hline$\oslash$ & 1,78 & 1,68 & 1,62 & 1,58 & 1,56 & 1,55 & 1,54 \\
\hline$M_{\mathrm{n}} / \mathrm{gmol}^{-1}$ & 16098 & 22894 & 29254 & 35276 & 41023 & 46538 & 51854 \\
\hline$M_{\mathrm{w}} / \mathrm{g} \mathrm{mol}^{-1}$ & 28698 & 38365 & 47360 & 55909 & 64125 & 72076 & 79806 \\
\hline $\begin{array}{l}m(\text { ost. M) /g } \\
m(\text { res. M)/g }\end{array}$ & 19,73 & 35,97 & 54,45 & 74,6 & 96,3 & 120,13 & 143,2 \\
\hline $\begin{array}{l}m(\text { ost. l) } / g \\
m(\text { res. I) } / g\end{array}$ & 0,038 & 0,038 & 0,038 & 0,038 & 0,038 & 0,038 & 0,038 \\
\hline
\end{tabular}




\section{Zaključak}

Rezultati provedenih računalnih simulacija polimerizacije potvrđuju da kemijska struktura, odnosno funkcijska skupina inicijatora kao i procesni uvjeti imaju presudan utjecaj na strukturnu građu sintetiziranih homopolimera, odnosno na vrijednosti brojčanih i masenih prosjeka molarnih masa te širinu raspodjele (disperznost), a također i na ukupni doseg reakcije polimerizacije. Upotrebom inicijatora koji posjeduje dvije peroksidne skupine različite toplinske stabilnosti mogu se ostvariti brojne prednosti u procesu homopolimerizacije stirena kao što su postizanje veće konverzije monomera pri dvostruko manjoj koncentraciji inicijatora, veće molekulske mase te nešto uža raspodjela molekulskih masa, što je od velike važnosti za njihovu primjenu. Dodatno, primjenom takvog tipa peroksidnog inicijatora proces proizvodnje može se provesti potpuno šaržno, uz povećanu djelotvornost inicijatora i bez preinaka reaktorskog sustava. Time se pojednostavljuje rad proizvodnog postrojenja i ostvaruju određene uštede. Provedena parametarska analiza pokazala je da se navedene prednosti ostvaruju samo pri optimalnim procesnim uvjetima, kao što su umjerena brzina dekompozicije inicijatora te uravnotežen odnos između radikala i molekula monomera u reakcijskoj smjesi tijekom cijelog vremena polimerizacije. Eksperimentalno je potvrđeno da primijenjeni dinamički matematički modeli izrađeni u sklopu računalnog programskog paketa ChemCAD pokazuju pravilne tendencije svojstava za sustave inicirane s monofunkcijskim inicijatorom, dok je za sustave inicirane difunkcijskim peroksidnim inicijatorom ostvareno i vrlo dobro slaganje s rezultatima računalne simulacije. Stoga dobiveni rezultati koji se odnose na proces homopolimerizacije stirena $u$ otopini uz difunkcijski peroksidni inicijator mogu poslužiti kao polazna osnova pri optimizaciji procesnih čimbenika za kopolimerizacije sa stirenom u otopini pri, na primjer, proizvodnji polimernih poboljšavala reoloških svojstava mazivih ulja. Time je moguće postići maksimalnu učinkovitost procesa proizvodnje uz dobivanje proizvoda željenih ili prihvatljivih primjenskih svojstava.

\section{Popis simbola i kratica List of symbols and abbreviations}

A - Arrheniusova konstanta, predeksponencijalni faktor - Arrhenius constant, pre-exponential factor

$c_{1} \quad-$ koncentracija inicijatora, $\mathrm{mol} \mathrm{dm}^{-3}$

- concentration of initiator, mol $\mathrm{dm}^{-3}$

$C_{10}$ - početna koncentracija inicijatora, $\mathrm{mol} \mathrm{dm}^{-3}$

- initial concentration of initiator, $\mathrm{mol} \mathrm{dm}^{-3}$

$C_{\mathrm{M}} \quad$ - koncentracija monomera, mol $\mathrm{dm}^{-3}$

- concentration of monomer, mol dm ${ }^{-3}$

$c_{\mathrm{M} 0}$ - početna koncentracija monomera, $\mathrm{mol} \mathrm{dm}^{-3}$

- initial monomer concentration, $\mathrm{mol} \mathrm{dm}^{-3}$

d - promjer reaktora, $\mathrm{cm}$

- diameter of the reactor, $\mathrm{cm}$

$Ð$ - disperznost

- dispersity
$E_{\mathrm{a}}$ - aktivacijska energija

- activation energy

f - djelotvornost inicijatora

- effectiveness of the initiator

$k_{\mathrm{d}} \quad-$ konstanta razgradnje, $\mathrm{s}^{-1}$

- rate constant of decomposition, $\mathrm{s}^{-1}$

$k_{\mathrm{i}} \quad-$ konstanta brzine inicijacije, $\mathrm{dm}^{3} \mathrm{~mol}^{-1} \mathrm{~s}^{-1}$

- rate constant of initiation, $\mathrm{dm}^{3} \mathrm{~mol}^{-1} \mathrm{~s}^{-1}$

$k_{\mathrm{p}} \quad-$ konstanta propagacije, $\mathrm{dm}^{3} \mathrm{~mol}^{-1} \mathrm{~s}^{-1}$

- rate constant of propagation, $\mathrm{dm}^{3} \mathrm{~mol}^{-1} \mathrm{~s}^{-1}$

$k_{\mathrm{t}} \quad-$ konstanta terminacije, $\mathrm{dm}^{3} \mathrm{~mol}^{-1} \mathrm{~s}^{-1}$

- rate constant of termination, $\mathrm{dm}^{3} \mathrm{~mol}^{-1} \mathrm{~s}^{-1}$

$k_{\mathrm{t} 0} \quad$ - konstanta terminacije pri $X=0, \mathrm{dm}^{3} \mathrm{~mol}^{-1} \mathrm{~s}^{-1}$

- rate constant of termination at $X=0, \mathrm{dm}^{3} \mathrm{~mol}^{-1} \mathrm{~s}^{-1}$

$M_{1} \quad$ - molarna masa monofunkcijskog inicijatora, $\mathrm{g} \mathrm{mol}^{-11}$

- molar weight monofunctional initiator, $\mathrm{g} \mathrm{mol}^{-1}$

$M_{\mathrm{n}} \quad$ - brojčani prosjek molarne mase, $\mathrm{g} \mathrm{mol}^{-1}, \mathrm{~kg} \mathrm{~mol}^{-1}$

- number-average molar mass, $\mathrm{g} \mathrm{mol}^{-1}, \mathrm{~kg} \mathrm{~mol}^{-1}$

$M_{\text {ST }} \quad$ - molarna masa stirena, $\mathrm{g} \mathrm{mol}^{-1}$

- molar weight of styrene, $\mathrm{g} \mathrm{mol}^{-1}$

$M_{\mathrm{w}} \quad$ - maseni prosjek molarne mase, $\mathrm{g} \mathrm{mol}^{-1}, \mathrm{~kg} \mathrm{~mol}^{-1}$

- mass-average molar mass, $\mathrm{g} \mathrm{mol}^{-1}, \mathrm{~kg} \mathrm{~mol}^{-1}$

p - radni tlak, bar

- working pressure, bar

$R \quad$ - opća plinska konstanta

- universal gas constant

$S^{2} \quad$ - srednje kvadratno odstupanje

- mean squared error

$T$ - termodinamička temperatura, $\mathrm{K}$

- thermodinamic temperature, $\mathrm{K}$

- vrijeme, s

- time, $\mathrm{s}$

$t_{1 / 2} \quad$ - vrijeme poluraspada, min

- half-time, min

$t_{\mathrm{p}} \quad-$ vrijeme reakcije, $\min , \mathrm{h}$

- reaction time, $\mathrm{min}, \mathrm{h}$

$V_{R}$ - obujam reaktora, $\mathrm{dm}^{3}, \mathrm{~cm}^{3}$

- volume of the reactor, $\mathrm{dm}^{3}, \mathrm{~cm}^{3}$

w - maseni udjel, $\%$

- mass fraction, \%

X $\quad$ - konverzija, \%

- conversion, $\%$

$\vartheta \quad$ - Celsiusova temperatura, ${ }^{\circ} \mathrm{C}$

- Celsius temperature, ${ }^{\circ} \mathrm{C}$

CAD - računalni programi za simulaciju

- computer-aided design

DI - difunkcijski inicijator

- bifunctional initiator

GPC, - kromatografija isključenjem po veličini

SEC - gel permeation chromatography, size exclusion chromatography

I - inicijator

- initiator

MI - monofunkcijski inicijator

- monofunctional initiator 
p. a. - analitička čistoća

- analytical grade

THF - tetrahidrofuran

- tetrahydrofuran

\section{Literatura \\ References}

1. Z. Gomzi, Kemijski reaktori, HINUS, Zagreb, 1998.

2. Z. Janović, Polimerizacije i polimeri, HDKI, Zagreb, 1997.

3. W. J. Yoon, Y. S. Kim, I. S. Kim, K. Y. Choi, Recent advances in polymer reaction engineering: Modeling and control of polymer properties, Korean J. Chem. Eng. 21 (2004) 147-167, doi: http://dx.doi.org/10.1007/BF02705393.

4. J. A. Beisenberger, D. H. Sebastian, Principles of Polymerization Engineering, Wiley, New York, 1983.

5. O. Vogl, G. D. Jaycox, Trends in polymer science - Polymer science in the $21^{\text {st }}$ century, Prog. Polym. Sci. 24 (1999) 3-6, doi: http://dx.doi.org/10.1016/S0079-6700(98)00019-7.

6. A. E. Hamielec, H. Tobita, H. Gerrens, Ullmann's Encyclopedia of Industrial Chemistry: Polymerization processes, $5^{\text {th }}$ Edition, VCH Publishers, New York, 1992.

7. V. Prasad, M. Schley, L.P. Russo, B. W. Bequette, Product property and production rate control of styrene polymerization, J Process Control, 12 (2002) 353-372, doi: http:// dx.doi.org/10.1016/S0959-1524(01)00044-0.

8. P. Rempp, E. W Merril, Polymer sythesis, John Wiley \& Sons, New York, 1998.

9. G. Odian, Principles of polymerization, Wiley, New York, 2004.

10. C. McGreavy, Polymer Reaction Engineering, Chapman \& Hall, New York, 1993.

11. H. Hammouri, T. F. McKenna, S. Othman, Applications of Nonlinear Observers and Control: Improving Productivity and Control of Free Radical Solution Copolymerization, Ind. Eng. Chem. Res. 38 (1999) 4815, doi: http://dx.doi. org/10.1021/ie9806996.

12. M. J. Scorah, R. Dhib, A. Penlidis, Use of Novel Tetrafunctional initiator in the free radical homo- and copolymerization of styrene, methyl methacryalte and $\alpha$-methyl styrene, J. Macromol. Sci. Part A 42 (2005) 403, doi: http://dx.doi. org/10.1081/MA-200054332.

13. V. Coessens, T. Pintauer, K. Matyaszewski, Functional polymers by atom transfer radical polymerization, Prog. Polym. Sci. 26 (2001) 337-377, doi: http://dx.doi.org/10.1016/ S0079-6700(01)00003-X.

14. K. Matyjaszewski, Controlled/living radical polymerization: Progress in ATRP, NMP and RAFT, American Chemical Society, Washington, 2000, doi: http://dx.doi.org/10.1021/bk2000-0768.

15. E. L. Madruga, From classical to living/controlled statistical free-radical copolymerization, Progr. Polym. Sci. 27 (2002) 1879-1927, doi: http://dx.doi.org/10.1016/S00796700(02)00023-0.

16. M. Klapper, K. Muellen, Controlled polymer synthesis in homogeneous and heterogeneous processes, Macromol. Symp. 163 (2001) 1-23, doi: http://dx.doi.org/10.1002/15213900(200101)163:1<1::AID-MASY1>3.0.CO;2-2.

17. T. Otsu, Iniferter concept and living radical polymerization, J. Polym. Sci. Part A: Polymer Chemistry 38 (2000) 2121-2136, doi: http://dx.doi.org/10.1002/(SICI)1099-
0518(20000615)38:12<2121::AID-POLA10>3.0.CO;2-X.

18. Z. Janović, A. Jukić, E. Vidović, Lj. Tomašek, Reakcije i procesi usmjerenih radikalnih polimerizacija, Polimeri 25 (2004) 68-76.

19. H. Fischer, The persistent radical effect in controlled radical polymerizations, J. Polym. Sci. Part A: Polymer Chemistry 37 (1999) 1885-1901, doi: http://dx.doi.org/10.1002/ (SICI)1099-0518(19990701)37:13<1885::AID-POLA1 > 3.3.CO;2-T.

20. M. Benbachir, D. Benjelloun, Investigation of free radical polymerization using diperoxyesters as bifunctional initiators, Polymer 42 (2001) 7727-7738, doi: http://dx.doi. org/10.1016/S0032-3861(01)00223-3.

21. F. L. Marten, A. E. Hamielec, Chain-length-dependent termination for free radical polymerization, Macromolecules 22 (1989) 3093-3098, doi: http://dx.doi.org/10.1021/ ma00197a033.

22. V. R. Kamath, New initiators for PS offer big efficiencies, Modern Plastics 58 (1981) 106-110.

23. I. Šoljić, A. Jukić, Z. Janović, Kinetički model polimerizacije uz difunkcionalni peroksidni inicijator, Polimeri 29 (2008) 21-29.

24. M. A. Villalobos, A. E. Hamielec, P. E Wood, Kinetic model for short-cycle bulk styrene polymerization through bifunctional initiators, J. Appl. Polym. Sci. 42 (1991) 629-641, doi: http:// dx.doi.org/10.1002/app.1991.070420309.

25. L. Cavin, A. Rouge, T. Meyer, A. Renken, Kinetic modeling of free radical polymerization of styrene initiated by the bifunctional initiator 2,5-dimethyl-2,5-bis(2-ethyl hexanoyl peroxy)hexane, Polymer 41 (2000) 3925-3935, doi: http:// dx.doi.org/10.1016/S0032-3861(99)00651-5.

26. J. Gao, K. D. Hungenberg, A. Penlidis, Process modelling and optimization of styrene polymerization, Macromol. Symp. 206 (2004) 509-522, doi: http://dx.doi.org/10.1002/ masy.200450239.

27. R. Dhib, J. Gao, A. Penlidis, Simulation of free radical bulk/ solution homopolymerization using mono- and bi-functional initiators, Polym. React. Eng. 8 (2000) 299-471, doi: http:// dx.doi.org/10.1080/10543414.2000.10744557.

28. K. Y. Choi, G. D. Lei, Modeling of free-radical polymerization of styrene by bifunctional initiators, AIChE J, 33 (1987) 2067-2076, doi: http://dx.doi.org/10.1002/aic.690331217.

29. K. Y. Choi, W. R. Liang, G. D. Lei, Kinetics of bulk styrene polymerization catalyzed by symmetrical bifunctional initiators, J. Appl. Polym. Sci. 35 (1988) 1547-1562, doi: http://dx.doi. org/10.1002/app.1988.070350612.

30. N. Früs, A. E. Hamielec, High-conversion diffusion-controlled polymerization of styrene, J. Appl. Polym. Sci. 27 (1982) 489505, doi: http://dx.doi.org/10.1002/app.1982.070270213.

31. ChemCAD v. 5.4, CC Polymer User Manual, Chemistation Inc., Houston, 2004.

32. A. Saltelli, K. Chan, M. Scott (eds.), Sensitivity Analysis, John Wiley \& Sons, New York 2000.

33. Initiators for high polymers, Akzo Nobel, June 2006.

34. Product Data Sheet: Trigonox ${ }^{\circledR}$ 21, Akzo Nobel, March 2006. (www.akzonobel-polymerchemicals.com)

35. Product Data Sheet: Trigonox ${ }^{\circledR} 29$, Akzo Nobel, March 2006. (www.akzonobel-polymerchemicals.com)

36. A. S. Almeida, K. Wada, A. R. Secchi, Simulation of styrene polymerization reactors: kinetic and thermodynamic modeling, Brazilian J. Chem. Eng. 25 (2008) 337, doi: http://dx. doi.org/10.1590/S0104-66322008000200012.

37. C. Kiparissides, Polymerization reactor modeling: A review of recent development and future directions, Chem. Eng. Sci. 
51 (1996) 1637-1659, doi: http://dx.doi.org/10.1016/00092509(96)00024-3.

38. R. M. Mortimer, S. Y. Orszulic, Chemistry and Technology of Lubricants, $2^{\text {nd }}$ ed., Chapman \& Hall, London, 1997, doi: http://dx.doi.org/10.1007/978-94-017-1021-3.
39. I. Šoljić Jerbić, J. Parlov Vuković, A. Jukić, Production and application properties of dispersive viscosity index improvers, Ind. Eng. Chem. Res. 51 (2012) 11914-11923, doi: http:// dx.doi.org/10.1021/ie301010n.

\title{
SUMMARY
}

\author{
Dynamic Simulation of Batch Polymerization Reactor \\ and Sensitivity Analysis of Styrene Homopolymerization \\ Ivana Šoljić Jerbić, Sunčica Kuzmić, and Ante Jukić*
}

\begin{abstract}
In this work, dynamic simulations of a batch reactor in the process of styrene homopolymerization in a xylene solution initiated with two types of peroxide initiators, monofunctional and bifunctional, was carried out. The monofunctional peroxide initiator has wide industrial applications, while the bifunctional initiator in preliminary studies has shown some advantages, such as the production of polymers with homogeneous structure along with achieving high or even complete conversion of monomers. Additionally, the reaction time can be significantly reduced with no modification of the reactor system. Computer simulation was performed using ChemCAD software for simulation of the chemical process and its integrated modules CC-Polymer developed exclusively for the analysis and design of radical and step polymerization processes. This software package based on the previously developed very complex kinetic models predicts the basic structural properties of polymers such as molar mass and its distribution (dispersity), which directly determines the quality and use of the final product. Dependencies of monomer conversion and structural characteristics of the polymers on the polymerization time obtained by computer simulation were compared with the experimental data. The satisfactory tendencies and a relatively good agreement were accomplished regarding the end of polymerization for most of the examined conditions. Additionally, a sensitivity study for homopolymeric system initiated with diperoxide initiator was performed. The effects of monomer concentration, initiator concentration, temperature and reaction time on the rate of polymerization (monomer conversion) and the main structural properties of polymers were examined.
\end{abstract}

\section{Keywords}

Styrene, solution polymerization, bifunctional peroxide initiators, batch polymerization reactor, dynamic simulation, sensitivity study

Department of Petroleum Refining

and Petrochemistry

Faculty of Chemical Engineering and Technology

University of Zagreb

Marulićev trg 19

10000 Zagreb, Croatia
Professional paper

Received December 5, 2013

Accepted May 14, 2014 